Buca Eğitim Fakültesi Dergisi, 2021, say1 52, s. 666-691

Araştırma Makalesi

\title{
Sosyal Bilgiler Öğretmen Adaylarının E-Portfolyo Kullanımları: Bir Durum Çalışması
}

\author{
E-Portfolio Usage of Social Studies Teacher Candidates: \\ A Case Study
}

\author{
Büket ŞEREFLI' $\dot{I}^{1}$ Erdi ERDOĞAN ${ }^{2}$
}

\begin{abstract}
${ }^{1}$ Arş. Gör., Türkçe ve Sosyal Bilimler Eğitimi Bölümü, Eğitim Fakültesi, Kırıkkale Üniversitesi, Türkiye, buket.serefli@kku.edu.tr, (https://orcid.org/0000-0002-8110-2943)

${ }^{2}$ Sorumlu Yazar, Dr. Öğretim Üyesi, Türkçe ve Sosyal Bilimler Eğitimi Bölümü, Ĕgitim Fakültesi, Kırıkkale Üniversitesi, Türkiye, erdierdogan90@hotmail.com, (https://orcid.org/0000 -0002-3921-575X)
\end{abstract}

\section{ÖZ}

$\mathrm{Bu}$ çalışmanın amacı, sosyal bilgiler öğretmen adaylarının elektronik portfolyo (e-portfolyo) sürecine yönelik deneyimlerinin incelenmesidir. $\mathrm{Bu}$ amaç doğrultusunda, araştırma nitel araştırma temelinde durum çalışması olarak tasarlanmıştır. Çalışma grubunun belirlenmesinde amaçsal örnekleme yöntemi kullanılmıştır. Araştırmaya 10 sosyal bilgiler öğretmen adayı dâhil edilmiştir. Araştırmada veri toplama aracı olarak odak grup görüşmesi, araştırmacı günlüğü ve yansıtma raporlarından yararlanılmıştır. Veri toplama araçlarından elde edilen veriler nitel içerik analizi ile çözümlenmiştir. Araştırma sonucunda eportfolyo kullanımının sosyal bilgiler öğretmen adaylarına akademik öz düzenleme, kalıcı öğrenme, zamanı verimli kullanma, iş yükünü azaltma, sınav kaygısını önleme, değerli hissetme, beceri, değer ve yeterlilik kazanımı gibi kişisel; ürün düzenleme, depolama ve koruma, ürüne erişim ve maliyeti azaltma gibi dijital etkilerde bulunduğu sonuçlarına ulaşılmıştır. Bunun yanı sıra e-portfolyo sürecinde akran etkileşimi ve akademisyen-öğrenci etkileşiminin ön plana çıktığı sonucuna da ulaşılmıştır. Sosyal bilgiler öğretmen adaylarının e-portfolyo sürecinde teknoloji okuryazarlığı ve yabancı dilbilgisi yeterlikleri gibi birey kaynaklı, internet bağlantısı ve teknolojik donanımdan kaynaklanan aksaklıklar gibi teknoloji kaynaklı sorunlarla karşılaştıkları ulaşılan diğer sonuçlardır.

Anahtar sözcükler: Sosyal bilgiler, e-portfolyo, durum çalışması, öğretmen adayı.

\begin{abstract}
This study aims to examine the experiences of social studies teacher candidates regarding the electronic portfolio (e-portfolio) process. For this purpose, the research was designed as a case study based on qualitative research. A purposive sampling method was used to determine the study group. The ten social studies teacher candidates were included in the study. Focus group interview, the researcher's diary, and reflection papers were used as data collection tools. The data were analyzed by qualitative content analysis. As a result of the research, it has been found that the use of e-portfolio has an impact on the personal characteristics of social studies teacher candidates such as academic self-regulation, permanent learning, efficient use of time, reducing workload, preventing exam anxiety, feeling valuable, gaining skills, value and competence. Apart from this, the use of e-portfolios has also created digital effects such as product arrangement, storage and protection, access to product, and cost reduction. In addition, it was concluded that peer and academician-student interaction came to the fore in the e-portfolio process. Other results are that social studies teacher candidates encounter individual problems such as technology
\end{abstract}


literacy and foreign grammar proficiency, and technology-related problems such as internet connection and technological equipment.

Keywords: Social studies, e-portfolio, case study, teacher candidate.

\section{GíRiş}

Öğretme-öğrenme sürecinde hem bireylere bilgi, beceri ve yeterliliklerin kazandırması durumunun hem de öğrenme hedeflerinin gerçekleşme düzeylerinin belirlenmesinde ölçme ve değerlendirmeden yararlanılır. Ölçme, bir bireyin ya da nesnenin belirli bir niteliğe sahip olma düzeyinin belirlenmesidir (Kan, 2019). Ölçme işlemi değerlendirme sürecine hizmet etmektedir (Semerci, 2015). Nitekim ölçme sonuçlarının ölçütlerle karşıllaştırılarak karara varma süreci değerlendirme olarak tanımlanmaktadır (Kilmen, 2019; Özçelik 2016; Turgut ve Baykul, 2019). Eğitimde değerlendirme; öğretim programının ve öğretimin etkililiğinin saptanmasını, eksikliklerin ve öğrenci başarısının belirlenmesini, öğrencilerin ilgi alanları doğrultusunda meslek ya da eğitim alanlarına yönlendirilmesini, öğretmen ve diğer paydaşlar hakkında karar vermeyi amaçlamaktadır (Doğan, 2019; Turgut ve Baykul, 2019). Böylece eğitimde değerlendirme işleminin farklı zamanlarda farklı amaçlar doğrultusunda yapılmasından dolayı birçok değerlendirme türü karşımıza çıkmaktadır. Bu değerlendirme türleri tanılayıcı değerlendirme, sürece yönelik değerlendirme (biçimlendirici) ve sonuca yönelik değerlendirme olarak üç başlık altında incelenmektedir (Kilmen, 2019). Türkiye'de 2005 yılı itibarıyla uygulamaya konulan öğretim programları kapsamında bir yaklaşım değişikliği yaşanmış ve değerlendirme süreci de bu değişimden etkilenmiştir. Uygulamaya konulan yapılandırmacı eğitim anlayışıyla ürüne yönelik değil süreç temelli değerlendirmelere odaklanılması gerekliliği belirmiştir. Sürece yönelik değerlendirmenin amac1, öğrenciye not vermek değil bildirimde bulunmaktır (Güler, 2020). Süreç temelli değerlendirme eğitim süreci devam ederken belirli aralıklarla yapılır. Böylece hem sistemin aksayan yönleri zamanında tespit edilerek müdahale edilir hem de eğitimin amacına ulaşıp ulaşmadığı sürekli olarak sınanabilir (Atılgan, 2019). Süreç temelli değerlendirme birçok ölçme aracıyla gerçekleştirilmektedir. Bunlardan biri de portfolyo değerlendirmesidir.

Portfolyo, önceden belirlenmiş program hedefleri ve puanlama kriterlerine uygun olarak hazırlanan, öğrencinin ilerleme ve gelişimini gösteren ürünlerin bütünüdür. (Gomez, 2000; Kan, 2007; Paulsen, Paulsen ve Meyer, 1991). Diğer anlamıla portfolyo, öğrenme sürecinin bir kaydıdır (Grace, 1993; Korkmaz ve Kaptan, 2002). Portfolyo sürecinde öğrencilerin belirlenmiş olan eğitim hedeflerine ilişkin değerlendirmede kullanılacak ürünleri dosyalarında toplamaları istenir. Böylelikle birey performansları ortaya çıkarılır. Portfolyolar, kullanım amacına, içeriğine ve içeriğinin kim tarafindan oluşturulduğuna göre çeşitli şekillerde sınıflandırılmıştır (Kan, 2007). Portfolyolar kullanım amaçlarına göre şu şekilde siniflandırılmaktadır (Alexiou ve Paraskeva, 2010, s. 3049-3050):

- Vitrin Portfolyosu: Öğrencilerin farklı konu alanlarındaki proje çalışmalarını göstermek amaciyla kullanılmaktadır.

- Değerlendirme Portfolyosu: Öğrencilerin belirli konu alanlarındaki yeterliliklerini belirlemek amaciyla kullanılır.

- Yansıtıcı Portfolyo: Öğrencilerin başarılarını ve bunların öğrenme hedefleriyle ilişkisini belirlemek amaciyla kullanılır.

- Gelişim Portfolyosu: Öğrencilerin zaman içerisindeki gelişimini takip etmek ve planlamak için kulanılır.

Columba ve Dolgos (1995) ise portfolyoları, içeriğe ve içeriğin kim tarafından oluşturulduğuna dayalı olarak şu şekilde bir sınıflama yapmışlardır: 
- Öğretmen-Öğrenci Portfolyosu: Portfolyonun içeriğine öğretmen ve öğrenci birlikte karar verirler.

- Etkinlik Portfolyosu: Portfolyonun içeriğini öğrencilerin kendilerini en iyi temsil ettiklerini düşündükleri çalışmalar oluşturur.

- Alternatif Öğretmen Değerlendirme Portfolyosu: Bu tür portfolyolarda öğretmenler öğrencilerin portfolyolarını yalnızca kendilerinin kullanımı ve değerlendirme aracı olarak saklarlar (Columba ve Dolgos, 1995'ten akt. Kan, 2007, s. 135-136).

Portfolyo değerlendirmede tek bir puana bağlı kalınmayıp süreçsel değerlendirme yapıldığ için dersin hedeflerinin gerçekleşme durumu ve dersin işlenme şekli devamlı gözden geçirilebilir. $\mathrm{Bu}$ sayede hem süreç hem de ürün değerlendirilmiş olur. Öğretmenler ve öğrenciler portfolyo değerlendirmede değerlendirme sürecine aktif katılım sağlar. Böylece öğrenciler kendilerini daha iyi tanır, öğretmenler de çalışmalardaki eksiklikleri fark edebilirler. Aynı zamanda öğrenciler sürecin bir parçası olduğu için nasıl değerlendirildiğini bilir, hangi zamanda nasıl öğrendiği hakkında ipuçları elde eder. Bunların yanı sıra portfolyo değerlendirme öğrencilerin kendi öğrenmelerinin sorumluluğunu almasını sağladığ i için sorumluluk duygularının gelişmesine de katkı sağlar (Çepni, 2015; Gilman, Andrew ve Rafferty, 1995; Kutlu, Doğan ve Karakaya, 2017; Valencia, 1990). Hem öğretmen hem öğrenci için bu gibi birçok yararı olan portfolyo, teknolojik gelişmelerin ölçme ve değerlendirmeye etki etmesiyle dijital ortamlara aktarılmış veya dijital ortamlarda üretilmeye başlanmıştır. Böylece geleneksel portfolyo, artık elektronik portfolyo (e-portfolyo) biçimini almıştır.

Alanyazında e-portfolyonun çeşitli şekillerde tanımlandığı görülmektedir. Chou'ya (2012) göre e-portfolyo öğrenme portfolyo dosyalarını kaydetmek ve depolamak için bilgisayar ve internet teknolojilerinin kullanılmasıdır. Gülbahar ve Köse (2006, s.77) de eportfolyoyu kısaca bireysel ürünlerin web tabanlı koleksiyonu olarak tanımlamıştır. Eportfolyonun en yaygın tanımlarından biri ise öğrenci ürünlerinin farklı formatlarda (video, ses, grafik, metin, vb.) teknoloji tabanlı olarak sunulmasıdır (Akçıl ve Arap, 2009; Barrett, 2000; Chantanarungpak, 2015). E-portfolyo geleneksel portfolyonun tüm avantajlarını içermesinin yanı sıra kendine özgü birçok avantajı da beraberinde getirmektedir. Öncelikle bir e-portfolyo geliştirmek öğrencilerin ve öğretmenlerin multimedya geliştirme becerilerine katkı sağlamaktadır (Barrett, 2000). Geliştirilen e-portfolyolara internet erişimi olan her yerden ulaşılabildiği için öğrenciler istedikleri zaman çalışmalarını düzenleyebilir, öğretmenler de öğrenci çalışmalarına hızlı bir şekilde dönüt verebilir. Fiziki bir alan kısıtlaması olmadığından çalışmalar kolay bir şekilde depolanabilir ve yırtılma, buruşma vb. zararlardan korunmuş olur. Teknoloji tabanlı olduğu için kolay paylaşılabilir. Böyle öğrenci-öğrenci ve öğretmen-öğrenci arasındaki etkileşim artar (Butler, 2006; Demirli ve Gürol, 2007; Kutlu, Doğan ve Karakaya, 2017; Mason, Pegler ve Weller, 2004).

E-portfolyo tüm bu avantajlarına karşın birtakım sınırlılıklara da sahiptir. Alanyazın incelendiğinde, e-portfolyoya ilişkin sınırlılıklar; (1) internet erişimi, (2) zaman ve iş yükü, (3) deneyimsizlik başlıkları altında incelenebilir. Örneğin, her ne kadar öğrencilere okulda yeterli altyapı sağlansa da özellikle kırsal alanlarda okul dışında sık sık internet erişimi sorunu yaşandığ için öğrenciler e-portfolyo sistemine ödev yüklerken sorun yaşamaktadırlar. Bunun yanı sıra öğrenciler sistemlerine ödev yüklemeyi ve çevrim içi ortamda tartışmalara katılmayı zor ve zaman alıcı bulmakta, bu nedenle ödevlerini sadece not almak için yapmaktadırlar. Ayrıca öğretmenlerin e-portfolyoyu öğretim ve değerlendirme aracı olarak kullanabilme düzeyleri ve öğrencilerin hangi performanslarının e-portfolyoya yüklemeleri gerektiklerine karar verebilme yetkinlikleri de önemli bir sorunsal kısmı oluşturmaktadır. (Kabilan ve Khan 2012; Meyer ve Latham, 2008; Poole ve diğerleri, 2008; Totter ve Wyss, 2019; Yusuf, 2017). E-portfolyo içerdiği tüm bu sinırlılıklara rağmen özellikle öğrencinin değerlendirme sürecine 
aktif katılımını sağlaması yönüyle yapılandırmacı yaklaşımda kullanılabilecek bir değerlendirme yöntemi olarak verimli olabilir.

Yapılandırmacı yaklaşım, öğrencinin neyi nasıl öğrendiğiyle ilgilenir (Tüfekçi Aslim, 2014). Böylece değerlendirme aşamasında öğrencilerin performans ve düşünce süreçlerine odaklanarak süreç içerisinde ne tür yeni düşünceler oluşturdukları belirlenir (Yeşilyaprak ve Uçar, 2019). Yapılandırmacı yaklaşımın üzerine inşa edilen Sosyal Bilgiler Öğretim Programı'nda da bireylerin süreç içinde ölçülen özelliklerinin (ilgi, başarı, değer, tutum...) değişebileceği için ölçme ve değerlendirmenin bu değişimleri dikkate alarak öğretmen ve öğrencinin aktif katılımı ile yapılması gerekliliği belirtilmiştir (Milli Eğitim Bakanlığı [MEB], 2018). Bu doğrultuda bakıldığında, Sosyal Bilgiler Öğretim Programı'nda yer alan hem süreç değerlendirme hem de öğrenci ve öğretmenin değerlendirme sürecine aktif katılımı vurgusunun portfolyo değerlendirmenin tanımıyla örtüştüğü söylenebilir. Bu benzerlikten yola çıkarak "Hangi öğrenci ne kadar öğrendi?" sorusunu geride bırakarak "Bu öğrenci ne biliyor?" sorusu ile ilgilenen portfolyo değerlendirmenin Sosyal Bilgiler Öğretim Programı için uygun bir değerlendirme yöntemi olduğu söylenebilir. Sosyal bilgiler dersinin dijital teknolojilerden yararlanmaya elverişli bir ders olduğu (Demirezen ve Keleş, 2020; Shriner ve diğerleri, 2010) göz önüne alındığında ise değerlendirme aşamasında e-portfolyolardan yararlanmanın süreci daha da kolaylaştıracağı öngörülmektedir.

Öğretimin planlanması, uygulanması, denetlenmesi ve eksik yönlerinin düzenlenmesi öğretmen tarafindan yapılır. Dolayısıyla öğretimin değerlendirmesi de öğretmen tarafindan yapılır (Atılgan, 2019). Bu yüzden Sosyal Bilgiler Öğretim Programı'nın uygulayıcısı olan sosyal bilgiler öğretmenlerinin meslek öncesi eğitimde e-portfolyo değerlendirmeyi deneyimlemiş olmalarının önemli olduğu söylenebilir. Alanyazın incelendiğinde öğretmen ve öğretmen adaylarının e-portfolyoya yönelik görüşlerinin belirlendiği birçok araştırmaya rastlanmıştır. $\mathrm{Bu}$ araştırmalara örnek olarak sınıf öğretmeni adaylarının e-portfolyo kullanımının pedagojik bilgileri, alan bilgileri, teknoloji kullanım becerileri ve düşünme becerilerine katkısının incelendiği (Anagün, Atalay ve Kandemir, 2018), sınıf öğretmenlerinin e-portfolyo hakkındaki farkındalıkları, e-portfolyonun işlevleri ve çıtılarına yönelik görüşlerinin incelendiği (Baş, Gök, ve Ayaz, 2020), fen Bilgisi ve sosyal bilgiler öğretmen adaylarının e-portfolyoyu tanımlamaları, gerçekleştirilen e-portfolyo sürecine yönelik görüşlerinin incelendiği (Çukurbaşı ve Kıyıc1, 2018), sosyal ağ sitesine entegre edilen eportfolyonun bilgisayar ve öğretim teknolojileri öğretmen adaylarının akademik başarılarına ve tutumlarına yönelik etkisinin incelendiği (Özgür, 2016), bir ilköğretim okulunda görev yapan sinıf öğretmenleri ve branş öğretmenlerinin e-portfolyoya yönelik görüşlerinin çeşitli değişkenler açısından incelendiği (Polat ve Köse, 2013), okul öncesi öğretmen adaylarının eportfolyo kullanımlarını ve kabul süreçlerinin incelendiği (Ledoux ve McHenry, 2006), eportfolyo kullanımının öğretmen adaylarının öğretmenlik yeterliliklerinin geliştirilmesi ve değerlendirilmesi üzerine etkilerinin incelendiği (Stryuyven, Blieck ve Roeck, 2014), öğretmen adaylarının e-portfolyo kullanımı sürecinde karşılaştığı avantaj, dezavataj ve engellerin incelendiği (Parker, Ndoye ve Ritzhaup, 2012), öğretmen adaylarının e-portfolyo kullanımının etkililiğine yönelik görüşlerinin incelendiği (Lin, 2008) araştırmalar gösterilebilir. Ancak tüm bu araştırmalara rağmen sosyal bilgiler öğretmen adaylarının eportfolyo sürecine ilişkin deneyimlerini inceleyen araştırmaların sınırlı sayıda olduğu görülmüştür. Bu eksiklikten hareketle araştırmanın amacı; sosyal bilgiler öğretmen adaylarının e-portfolyo sürecine yönelik deneyimlerinin incelenmesidir. Bu amaç doğrultusunda araştırma sürecinde aşağıdaki alt problemlere yanıt aranmıştır.

1. Sosyal bilgiler öğretmen adaylarının e-portfolyo kullanım sürecinde hangi bireysel yararlar ortaya çıkmıştır?

2. Sosyal bilgiler öğretmen adayları e-portfolyo kullanarak akranlarıyla nasıl bir etkileşime girmişlerdir? 
3. E-portfolyo uygulaması öğretmen adayı-akademisyen ilişkisine nasıl bir etkide bulunmuştur?

4. Sosyal bilgiler öğretmen adayları e-portfolyo uygulamasında hangi teknolojik yararlarla karşılaşmışlardır?

5. Sosyal bilgiler öğretmen adaylarının e-portfolyo kullanım sürecinde ortaya çıkan sorunlar nelerdir?

\section{YÖNTEM}

\subsection{Araştırma Modeli}

$\mathrm{Bu}$ araştırma, sosyal bilgiler öğretmen adaylarının e-portfolyo kullanımı sürecindeki deneyimlerini ortaya çıkarmayı amaçladığı için nitel araştırma temelinde bir durum çalışması olarak tasarlanmıştır. Durum çalışması, en basit tanımıyla belirli bir olgunun ya da olayın derinlemesine incelenmesini amaç edinen bir nitel araştırma desenidir (Glesne, 2015). Diğer bir deyişle, durum çalışması sınırları çizilmiş bir alanda belirli bir sistemin (birey, program, grup vb.) yoğun bir biçimde betimlenmesine ve incelenmesine olanak tanıyan bir araştırma desenidir (Merriam, 2013). Durum çalışmaları araştırmacı müdahalesi dışındadır. Bu konuda Yin (2018), durum çalışmasının araştırma sürecinde müdahale bulundurmayan, neden-nasıl sorularına cevap arayan ve güncel bir olguyu gerçek yaşam sınırları içerisinde inceleyen bir yapıda olduğunu belirtmektedir. Durum çalışmaları, sınırlı bir yapı üzerine inşa edilir. Bu sınırlılık zaman, yer ve çalışma grubu üzerinden oluşturulabilir (Creswell, 2017). Durum çalışmaları, yapısı dolayısıyla da farklı kategorilere ayrılabilmektedir. $\mathrm{Bu}$ noktada alanyazında kabul edilen sinıflandırmalardan biri Yin (2018) tarafından gerçekleştirilmiştir. Bu kapsamda durum çalışmaları, tekli-bütüncül, tekli-gömülü, çoklu-bütüncül ve çoklu-gömülü olmak üzere dört boyutlu bir sınıflandırmaya sahiptir. $\mathrm{Bu}$ araştırmada, sosyal bilgiler öğretmen adaylarının "Sosyal Bilgiler Öğretiminde Materyal Geliştirme" dersindeki 10 haftalık e-portfolyo kullanım deneyimleri incelendiği için tekli-bütüncül durum çalışmasından yararlanılmıştır. Teklibütüncül durum çalışması deseninin seçilmesinin nedeni; araştırma odağının tek bir duruma ve alt birime yöneltilmiş olmasıdır.

\subsubsection{Durum}

Araştırma kapsamında, Sosyal Bilgiler Eğitimi Anabilim Dalı üçüncü sınıfında seçmeli bir ders olan "Sosyal Bilgiler Öğretiminde Materyal Geliştirme" dersinde değerlendirme süreçlerinde öğretmen adaylarının e-portfolyo kullanımı durumuna odaklanılmıştır. Durumun seçilmesinin temel nedeni; süreç odaklı değerlendirmelerin uygulamanın gerçekleştirildiği anabilim dalında tercih edilmemesidir. Bunu doğrulamak için öncedeki dönemlerde anabilim dalına ait derslerde gerçekleştirilen değerlendirmeler incelenmiş ve tüm derslerde değerlendirmelerin sonuç odaklı olduğu görülmüştür. Buna ek olarak, öğrencilerle uygulamadan önceki dönemde gerçekleştirilen görüşmelerde klasik bir sınavın ya da tek bir araştırma ödevinin kendilerinin derse ve ögrenmeye karşı motivasyonlarını düşürdüğü belirtilmiştir. Bu uygulamalar, durumun belirlenmesinde ve sınırlarının çizilmesinde etkili olmuştur. Ayrıca araştırmacıların çalışma alanlarının sosyal bilgiler ve öğretim teknolojileri etkileşimi üzerine olması da durumun tercih edilmesinin ve incelenmesinin bir gerekçesini oluşturmuştur. İncelenen durum, on haftalık bir süreyi kapsamaktadır. Her hafta öğrencilerden, gerçekleștirilen dersle ilgili bir ürünü belirlenen tarihe kadar e-portfolyolarına eklemeleri istenmiştir. Bu süreç, on öğrenciyle başarılı bir şekilde yürütülmüştür. Dersin ara ve dönem sonu değerlendirmeleri önceden tasarlanmış puanlama anahtarına uygun olarak öğrenci portfolyoları üzerinden gerçekleştirilmiştir. E-portfolyo sürecine ilişkin ayrıntılar Tablo 1'de sunulmuştur. 
Tablo 1. E-portfolyo Süreci

\begin{tabular}{|c|c|c|}
\hline Hafta & Konu & Beklenen Ürün \\
\hline 1 & $\begin{array}{l}\text { Yaşantı Konisi, basılı ve dijital materyal } \\
\text { geliştirme farkl1lıkları ve benzerlikleri }\end{array}$ & Rapor \\
\hline 2 & $\begin{array}{l}\text { Basılı materyal geliştirmede tasarım } \\
\text { ilkeleri }\end{array}$ & Rapor \\
\hline 3 & $\begin{array}{l}\text { Basılı materyal geliştirme süreci ve basılı } \\
\text { materyallerin öğrenmeye etkileri }\end{array}$ & $\begin{array}{l}\text { Bilgilendirici sunu tasarımı ve e- } \\
\text { portfolyo kullanımına yönelik } \\
\text { yansıtma raporu }\end{array}$ \\
\hline 4 & $\begin{array}{l}\text { Dijital materyal geliştirme süreci ve dijital } \\
\text { materyallerin ögrrenmeye etkileri }\end{array}$ & Alanyazın taraması \\
\hline 5 & Animaker aracı ile animasyon geliştirme & $\begin{array}{l}\text { Senaryo yazımı ve geliştirilen } \\
\text { materyal }\end{array}$ \\
\hline 6 & Padlet aracı ile dijital pano oluşturma & Geliştirilen materyal \\
\hline 7 & $\begin{array}{l}\text { Blippar aracı ile artırılmış gerçeklik } \\
\text { ortamı tasarımı }\end{array}$ & $\begin{array}{l}\text { Geliştirilen materyal ve e- } \\
\text { portfolyo kullanımına yönelik } \\
\text { yansıtma raporu }\end{array}$ \\
\hline 8 & $\begin{array}{l}\text { Educandy aracı ile dijital bulmaca } \\
\text { geliştirme }\end{array}$ & Ders planı ve geliştirilen materyal \\
\hline 9 & Edmodo aracı ile sanal sınıf oluşturma & $\begin{array}{l}\text { Ekran görüntüsü destekli tasarım } \\
\text { raporu }\end{array}$ \\
\hline 10 & Piktochart aracı ile infografik tasarımı & $\begin{array}{l}\text { Geliştirilen materyal ve e- } \\
\text { portfolyo kullanımına yönelik } \\
\text { yansıtma raporu }\end{array}$ \\
\hline
\end{tabular}

E-portfolyo sürecinin yürütülmesinde Seesaw Web 2.0 aracından yararlanılmıştır. Seesaw, ölçme ve değerlendirme sürecinde kullanılabilen Amerika Birleşik Devletleri merkezli bir uzaktan sınıf yönetim aracıdır. Her ay yaklaşık on milyon katılımcı (öğretmen, öğrenci ve ebeveyn) tarafindan kullanılmaktadır. Basit bir arayüze ve kullanım diline sahip olan Seesaw arac1 öğrencilerin ödevlerini ve ürünlerini yüklemelerine, öğretmenlerin bunlara dönüt vermelerine ve ebeveynlerin de bu süreci izleyebilmelerine olanak tanımaktadır. Bu araştırma kapsamındaki durum için de e-portfolyo sürecinin uygulanmasında Seesaw aracı işe koşulmuş ve öğrencilerin süreçteki deneyimlerinin ortaya çıkarılması amaçlanmıştır. Aşağıda Şekil 1'de Seesaw aracının arayüzünden bir görsel sunulmaktadır. Görselde araştırmacı ve katılımcı bilgilerinin gizliliğini sağlamak için karalamalar gerçekleştirilmiştir. 


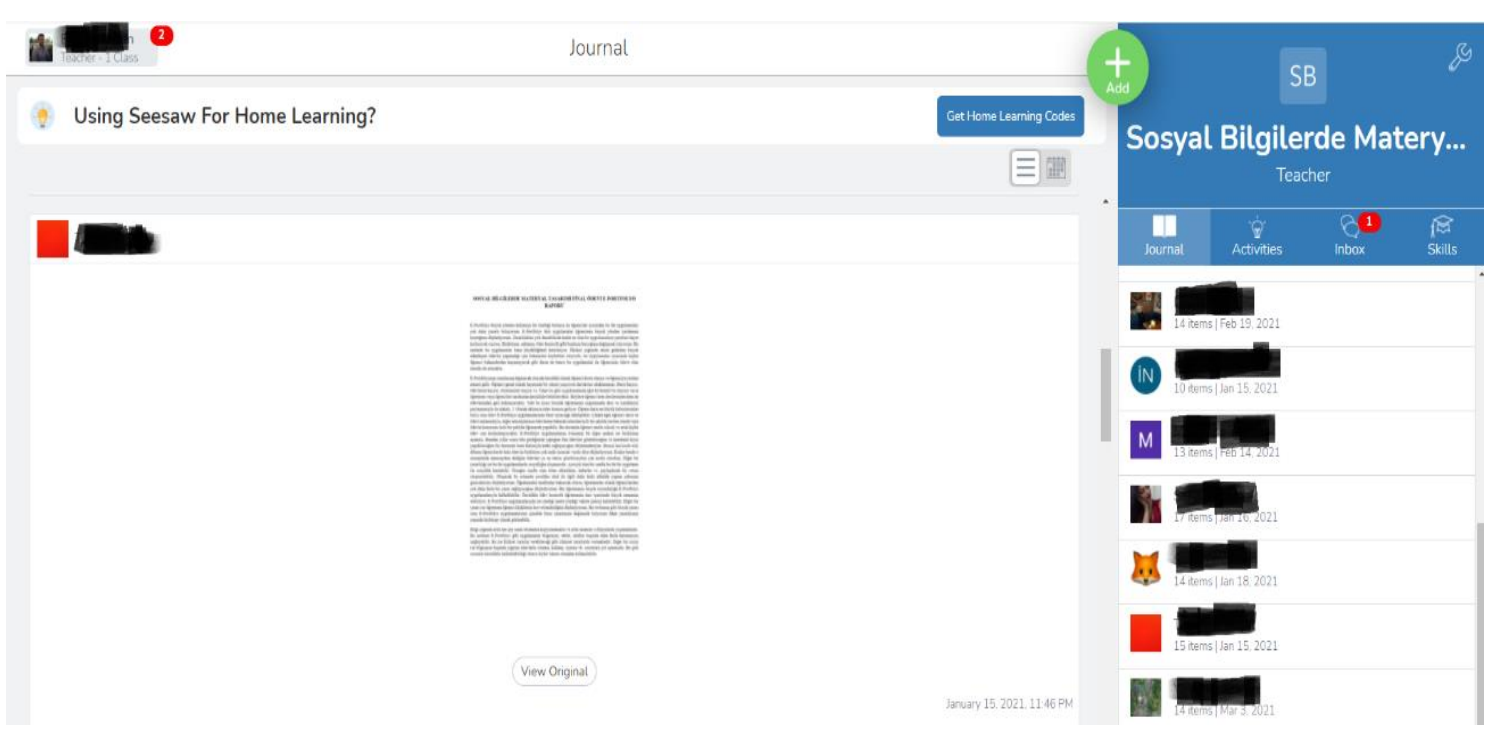

Şekil 1. Seesaw Aracının Arayüzü

\section{2. Çalışma Grubu}

Nitel araştırmalar, geniş bir katılımcı grubuna ulaşmak yerine sınırları belirli bir çalışma grubunu içeren araştırmalardır. Bu nedenle çalışma grubunun belirlenmesinde araştırmanın amacına uygun olarak sınırların iyi çizilmesi gerekmektedir. Bu araştırma da nitel bir durum çalışması olduğu için belirli özellikleri içeren katılımcıların araştırma sürecine dâhil edilmesi sağlanmıştır. Bunun için seçkisiz olmayan örnekleme yöntemlerinden biri olan amaçsal örnekleme yönteminden yararlanılmıștır. Amaçsal örnekleme, nitel araştırmanın doğasına uygun bir örnekleme şeklidir (Patton, 2014). Bu tür örnekleme, araştırmanın amacına uygun olarak katılımcıların belirlendiği bir örnekleme türüdür (Fraenkel, Wallen ve Hyun, 2012). Araştırmada katılımcıların belirlenmesinde, Sosyal Bilgiler Eğitimi Anabilim Dalı'nda öğrenimine devam ediyor olmaları, seçmeli bir ders olan "Sosyal Bilgiler Öğretiminde Materyal Geliştirme" dersine kayıtlı olmaları, internete erişimlerinde herhangi bir sorun yaşamamaları ve sürece katılmada gönüllü olmaları şartları aranmıştır. Bu gereksinimleri karşılayan İç Anadolu Bölgesi'nde yer alan bir devlet üniversitesinin Eğitim Fakültesi Sosyal Bilgiler Eğitimi Anabilim Dalı'nda öğrenimlerine devam eden on öğrenci araştırmaya dâhil edilmiş, üç öğrenci ise kendi istekleriyle araştırma süreci dışında tutulmuştur. Katılımcıların cinsiyet dağılımı ikisi erkek ve sekizi kadın şeklindedir. Araştırmanın "Bulgular ve Yorum" bölümünde katılımcılar "Ö1, Ö2, Ö3...." biçiminde kodlanarak kimliklerinin gizliliği sağlanmıştır.

\subsection{Araștırmacının Rolü}

Nitel araştırma yaklaşımında araştırmacı elde ettiği verileri anlamlandıran ve yorumlayan bir bağlamda hareket ettiği için katılımcılarından biri olarak kabul edilmektedir (Stake, 2010). $\mathrm{Bu}$ durum çalışmasında da araştırmacılar dinamik olarak sürecin bir parçasıdır. Böylelikle araştırmacılar süreçte hem araştırmayı tasarlayan hem de durumu detaylıca inceleyen iki role sahiptir. Araştırmacıların ikisi de bir devlet üniversitesinde Sosyal Bilgiler Eğitimi alanında çalışmaktadır. Böylece uzun süredir lisans öğrencilerinin ölçme ve değerlendirme süreçlerindeki deneyimlerine ilişkin bilgi sahibidirler. Ayrıca iki araştırmacının da araştırma alanları sosyal bilgiler ve öğretim teknolojileri ilişkisi üzerinedir. Bu nedenle e-portfolyo kullanımında da tecrübelidirler. Araştırmacılar, incelenen duruma hiçbir müdahalede bulunmamışlardır. Sürecin doğal seyrinde devam ettirilmesine özen göstermişlerdir. Son olarak, verilerin toplanmasında, durumun anlamlandırılmasında ve yorumlanmasında araştırmacıların bakış açıları etkili olmuştur. Her ne kadar objektifliğe özen gösterilmesine, etik ilkelere uygun hareket edilmesine ve öğrenci deneyimleri doğrudan alıntılarla desteklenmesine rağmen durumun analizinde kısıtlı da olsa öznellik belirmiş olabilir. Bu sınırlılık araştırmacılar tarafından kabul edilmektedir. 


\subsection{Veri Toplama Araçları}

Araştırmanın veri toplama araçlarını odak grup görüşmesi, araştırmacı günlügü ve yansıtma raporları oluşturmaktadır. Bu araçlar, ayrıntılı biçimde aşağıda açıklanmıştır.

\subsubsection{Odak Grup Görüşmesi}

Araştırmada kullanılan veri toplama araçlarından biri odak grup görüşmesidir. Odak grup görüşmesi, sosyal bilim araştırmalarında grup dinamiklerinin derinlemesine incelenmesine ve zengin bir biçimde betimlenmesine olanak tanıyan bir veri toplama aracıdır (Matthews ve Ross, 2010). Bu araştırmada da çalışma grubuyla bütünleşmiş bir durum bulunduğu için durumun derinlemesine incelenmesinde odak grup görüşmesinden yararlanılmıştır. $\mathrm{Bu}$ aracın seçilmesinin güçlü nedenlerinden biri de grup dinamiğini etkileşimli bir biçimde yansıtmaya olanak tanımasıdır. Görüşme formunun geliştirilmesinde ilk olarak alan yazın taramasından yararlanılarak 14 sorudan oluşan bir soru havuzu oluşturulmuştur. Ardından taslak görüşme formu iki alan uzmanı tarafından incelenmiştir. Dönütler neticesinde, üç sorunun araştırma amacına hizmet etmediği ve çıkarılması gerektiği, iki sorunun ise eklenmesi gerektiği belirtilmiştir. İlgili düzeltmeleri gerçekleştirilen görüşme formu 13 sorudan oluşmaktadır. Odak grup görüssmesi, araştırma sürecinin sonunda video konferans aracı üzerinden gerçekleştirilmiştir. Görüşmeyi planlamak için öğrencilerle WhatsApp grubu üzerinden iletişime geçilmiş ve ortak bir tarih-saat belirlenmiştir. Tüm katılımcıların katıldığı görüşme yaklaşık olarak 140 dakika sürmüştür. Odak grup görüşmesi kategorilerin geliştirilmesinde de en önemli etkiyi yapmıştır.

\subsubsection{Araștırmacı Günlüğü}

Durum çalışmalarında kullanılabilecek veri toplama araçlarından biri de araştırmacı günlüğüdür. Durumu anlayabilmek ve analiz edebilmek için sürecin detaylı olarak betimlenmesi gerekmektedir. Bu noktada, araştırmacı günlüğü de sistematik olarak veri toplamaya elverişli bir veri toplama aracı olarak araştırmanın amacına hizmet etmektedir. Araştırmacı günlügüü, araştırmacının düşüncelerini ve hislerini kayıt altına alarak sürecin betimlenmesine olanak tanıyan bir veri toplama aracıdır (Mills, 2007). Böylelikle araştırmacı kayıt altına aldığı süreci inceleyebilir, analiz edebilir ve değerlendirebilir (Cochran Smith ve Lytle, 1993). Bu araştırmada da 10 haftalık süreç boyunca araştırmacı günlüğü tutulmuştur. Araştırmacı günlüğünün verileri, her hafta dersin son kısmında öğrencilerle gerçekleştirilen değerlendirmelerden ve Seesaw aracının haftalık olarak incelenmesinden meydana gelmektedir.

\subsubsection{Yansitma Raporu}

Araştırma sürecinde incelenen durumun bireysel olarak değerlendirilmesinde e-portfolyo uygulama sürecine yönelik yansıtma raporlarından yararlanılmıştır. 10 haftalık süreçte öğrenciler tarafından üçer yansıtma raporu yazılmıştır. Böylelikle öğrencilerin içinde bulundukları duruma ilişkin deneyimleri, süreklilik ve değişim açısından belirli aralıklarla incelenmiştir. Ayrıca, odak grup görüşmesi ve araştırmacı günlüğü ile elde edilen verilerin farklı bir veri toplama aracıyla da desteklenmesi amaçlanmıştır. Böylelikle, odak grup görüşmesiyle grup, araştırmacı günlüğüyle araştırmacı gözünden incelenen süreç, yansıtma raporlarıyla da öğrencilerin bireysel bakış açılarından değerlendirilmiştir.

\subsection{Araştırmada İnandırıcılık, Doğrulanabilirlik ve Aktarılabilirlik}

Nitel araştırmalar, hem bağlı olduğu paradigma farklılığı hem de doğası gereği nicel araştırmalardan geçerlik ve güvenirlik sınaması yönünden oldukça farklıdır. Geçerlik ve güvenirlik kavramlarının nitel araştırmada karşılığ inandırıcılık, doğrulanabilirlik ve aktarılabilirlik olarak karşımıza çıkmaktadır. Bu yönüyle, nitel araştırmada inandırıcılığı, doğrulanabilirliği ve aktarılabilirliği sağlamak için bir dizi işlem gerçekleştirilmektedir

(Maxwell, 1992). Bu araştırmada da gerekli önlemler alınmıştır. Öncelikle araştırmanın tasarlanması esnasında amaca uygun bir nitel araştırma deseni seçilmiştir. Buna ek olarak, 
araştırmada kullanılacak veri toplama araçlarının ve katılımcıların da araştırma amacına ve desenine uygun biçimde belirlenmesi sağlanmıştır. Ayrıca araştırmanın çalışma grubunun özellikleri detaylandırılarak tanımlanmış ve veri toplama aracı için uzman görüşleri alınmıştır. Araştırma sürecinde sistematik bir biçimde veri toplanmış, veri kaybının önüne geçmek için ses kayıt cihazı kullanılmış, katılımcıların tutarlılı̆̆ını sağlamak için veri çeşitlemesi gerçekleştirilmiş, veri toplama ve analiz süreci detaylı olarak betimlenmiştir. Bunların haricinde elde edilen tüm veriler katılımcılar tarafından teyit edilmiş ve araştırma verileri iki araştırmacı tarafından bağımsız biçimde kodlanmıştır. Son olarak, bulgular bölümünde katılımcıların görüşleri doğrudan alıntılarla sunulmuştur.

\subsection{Verilerin Analizi}

Araştırma verileri nitel içerik analizi (qualitative content analysis) aracılığıyla çözümlenmiştir. İçerik analizi, yoğun nitel veriler içerisindeki tutarlılık ve anlamları belirlemek amacıyla durum çalışmalarında da sıklıkla kullanılan bir analiz türüdür (Patton, 2014). Araştırma verilerinin analizinde tümevarımsal bir bakış açısı sahiplenilerek öncelikle ham veriler iki araştırmacı tarafından okunmuştur. Okumalar sonucunda araştırmacıların metnin analizine kendilerini hazır hissetmeleriyle birlikte bağımsız kodlamalar gerçekleştirilmiştir. Böylelikle araştırmacıların birbirini etkilemesinin önüne geçilmiştir. Ardından, araştırmacılar kodlama yaptıkları veri setlerini değişerek birbirinin kodlamalarını kontrol etmiş̧ler ve görüş ayrılığ 1 yaşanan kodları farklı bir renkle belirtmişlerdir. Bu işlemin ardından araştırmacılar bir araya gelerek görüş ayrılığı yaşadıkları kodları tartışmışlar ve uzlaşmak için çaba sarf etmişlerdir. Görüş ayrılıklarına ilişkin gerçekleştirilen görüşmeler sonucunda Miles ve Huberman (1994) tarafından alanyazına kazandırılan kodlama güvenirlik hesaplamasına göre (Güvenirlik= Görüş Birliği / (Görüş Birliği + Görüş Ayrılı̆̆ $)$ araştırmacılar arasında \%93 uyum oranına ulaşılmıştır (220 kod üzerinde uyum sağlanırken, 16 kod üzerinde uzlaşılamamıştır). Bunun ardından kategori tasarımına gidilmiştir. Bu süreçte de birbiriyle ilişkili kodlar bir araya getirilmiş, "Kişisel Etkiler", "Akran Etkileşimi”, "Öğrenci-Akademisyen Etkileşimi”, "Dijital Etkiler" ve "Sorunlar" kategorileri açığa çıkmıştır. Son olarak, araştırma verileri doğrudan alıntılarla desteklenmiştir.

\section{BULGULAR}

Araştırma kapsamında, sosyal bilgiler öğretmen adaylarının e-portfolyo uygulama sürecine ilişkin deneyimlerini ortaya çıkarmak için odak grup görüşmesi gerçekleştirilmiş, öğrencilerden yansıtma raporları toplanmış ve araştırmacılar tarafından araştırmacı günlüğü tutulmuşstur. Araştırmanın bu bölümünde üç veri toplama aracından elde edilen veriler "Kişisel Etkiler", "Akran Etkileşimi”, "Öğrenci-Akademisyen Etkileşimi”, "Dijital Etkiler" ve "Sorunlar" kategorileri altında toplanmış ve doğrudan alıntılarla desteklenmiştir. Şekil 2'de kategorilere ilişkin detaylar sunulmaktadır. 


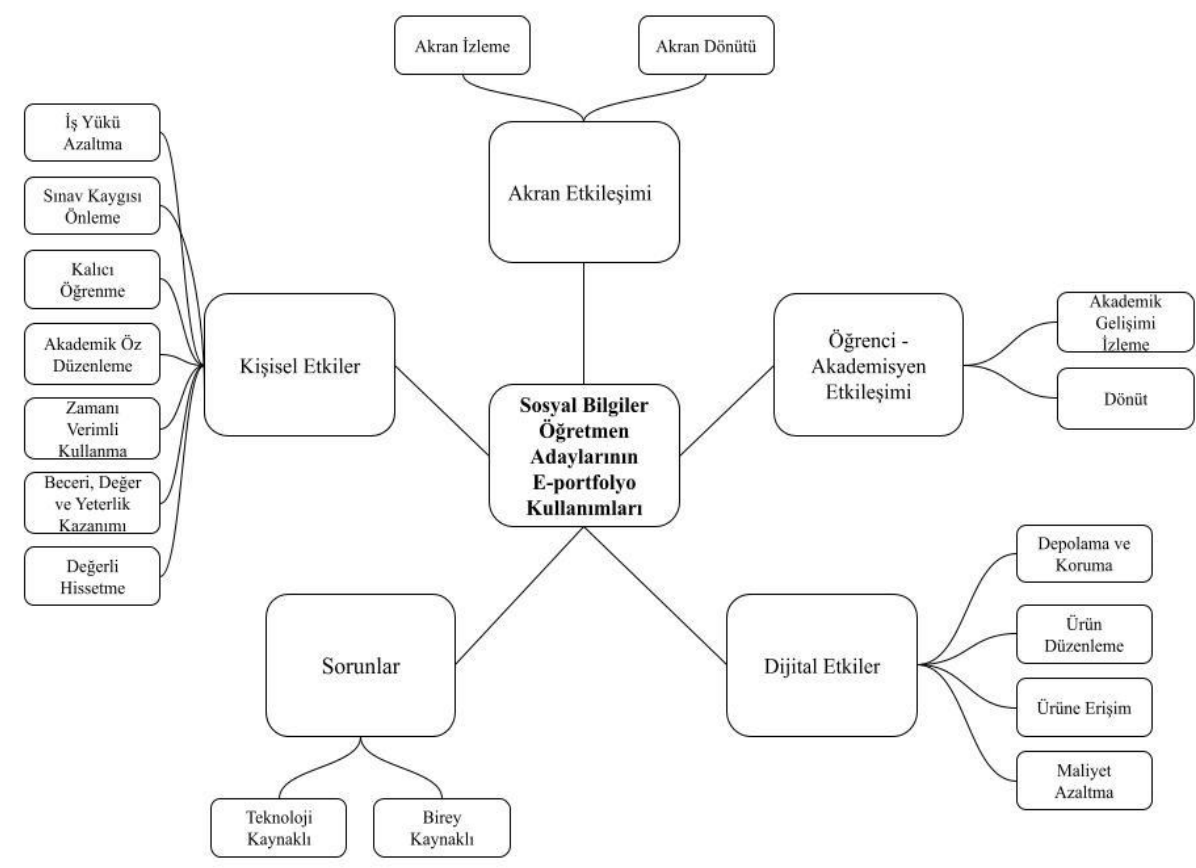

Şekil 2. Araştırmada Ortaya Çıkan Kategoriler

\subsection{Kişisel Etkiler}

Sosyal bilgiler öğretmen adaylarından elde edilen veriler incelendiğinde "Kişisel Etkiler" kategorisinin baskın bir biçimde ortaya çıktığına ulaşılmıştır. Öğretmen adayları bu kategori kapsamında e-portfolyo kullanımından kaynaklı birçok kişisel faydayı dile getirmişlerdir.

Öğretmen adaylarının en çok üzerinde durdukları kişisel etki akademik öz düzenleme becerileri üzerine gerçekleşmiştir. Katılımcılar, e-portfolyo sürecinin kendilerinin bilişsel farkındalıklarını artırdığını belirtmişlerdir. Böylece katılımcılar eksiklerini dijital ortamdaki süreç temelli yaklaşımdan dolayı daha kolay görebilmiş ve bunları düzeltme yoluna gitmişlerdir. Ders kapsamındaki eksikliklerini tamamlayarak akademik gelişimlerindeki boşlukları doldurmuşlardır. Bu durum, katılımcıların e-portfolyo kullanımından dolayı kendi öğrenmelerine daha yüksek ilgi gösterdiğinin önemli bir kanıtı niteliğindedir. Akademik öz düzenleme vurgusu hem odak grup görüşmesinde hem yansıtma raporlarında hem de araştırmacı günlüğünde baskın bir biçimde yer almaktadır.

Ben kendimi ifade etme noktasında kendime çok güvenen biriyim. Ama ödevlerimi elektronik portfolyoma yüklediğimde kendi eksiklerimi görebildim. Kendimi daha çok geliş̧tirebildim. Benim yaptığım çok güzel oldu şeklindeki düşünceden çıktım, eksiklerimi görüp üzerine daha çok şey ekledim. (Ö4)

Öz değerlendirme konusunda da çok faydasını gördüm. Çünkü yüklediğim ilk ödev ile son ödev arasında gerçekten çok fazla fark vardl. Bunun farkina diğer derslerde varamıyoruz. ...̈̈z değerlendirme açısından da öğrencinin kendini bilmesi açısından da çok faydalı bir uygulama oldu. (Ö5)

...ödevlerime girip tekrar bakarak eksiğimi görebiliyorum bunun da her derste kullanıldığını düşü̈ndüğümde bizim için ekstra bir avantajı olduğunu gösteriyor. ...diğer arkadaşlarımın ödevlerini görebilmem kendi ödevimle karşılaştırmam yanlış ve 
doğruları daha iyi anlamam da etkili oluyor. Ve eksikliklerimi giderebiliyorum. (Yansitma Raporu - Ö2)

Akademik öz düzenlemeye ilişkin vurgu araştırmacı günlüğünde de yer bulmuştur. Araştırmacılar, öğrencilerin Seesaw sistemi üzerindeki ödev yükleme ve silme hareketlerinin öğrenciler tarafından derste dile getirildiğini belirtmiştir.

Dersin son kısmında bazı ögretmen adayları ilk hafta yükledikleri raporda bazı eksiklikler olduğunu ve bunlar düzenleyip yeniden yüklediklerini ifade ettiler. Bu durum, ilk haftadan itibaren eksikliklerin iyi bir şekilde değerlendirildiğinin önemli bir göstergesiydi. (Araştırmacı Günlügü 1. Hafta)

Sosyal bilgiler öğretmen adayları e-portfolyo kullanım sürecinin kendilerine zamanı verimli kullanmada kolaylık sağladığını ifade etmişlerdir. Katılımcılar e-portfolyo sürecinden kaynaklı olarak akranlarıyla ve dersin yürütücüsüyle daha hızlı etkileşime geçtiklerinden ve zamanı doğru yönettiklerinden dolayı üretkenliklerinin de arttığını belirtmişlerdir. Bu bulgu, eportfolyo kullanımının zamanı verimli kullanmayı sağlamasıyla akademik performansı artırdı $\breve{1} 1$ şeklinde yorumlanabilir.

Yani mesela materyalimi arkadaşlarıma kalkıp tek tek göndermek yerine oraya yüklediğim zaman arkadaşlarım olumlu veya olumsuz olarak yorumlar yapmıştı. Zaman tasarrufu diyebiliriz aslında buna. (Ö8)

Derste zaman kaybının önüne geçtiğini düşünüyorum. Sinıfta bütün ögrencilerin raporlarını ödevleri okunamadı̆̆ için sinıftaki ögrenciler de duymuyor. Bu uygulamada sinıfta isteyen herkes birbirinin ödevlerine bakıp okuyabiliyor. Öğretmenlere büyük bir kolaylık sağladığını düşünüyorum ödevleri kâğıtları saklamak, okuduktan sonra ögrencilere geri vermek gibi bir zaman kaybı oluşturmaz. (Yansitma Raporu - Ö10)

...Derste yapılan değerlendirmede ise zamanı verimli kullanma üzerine görüşler ifade edildi. Öğretmen adayları, gerçekleştirdikleri sorumlulukları her hafta dersin akademisyenine ve arkadaşlarına göndermenin çok vakit aldığın vurguladılar. Bunun yerine ödevlerini e-portfolyolarina yüklediklerinde hem akademisyenin hem de arkadaşlarının ödevlerine daha kısa sürede ulaşabildiğini söylediler. Bu durumu verimli zaman kullanımı olarak tanımladılar. (Araştırmacı Günlüğü 4. Hafta)

Birçok uzman okullarda salt bilgi aktarımının günümüz eğitim anlayışıyla çeliştiğini, bunun yerine aktarılacak bilginin uygun beceri, değer ve yeterliklerle harmanlaması ihtiyacını belirtmektedir. Bu araştırmada da sosyal bilgiler öğretmen adaylarının e-portfolyo kullanımları sonucunda değer, beceri ve yeterlik kazanımına yönelik geliştirici etkilere ulaşılmıştır. Katılımcılar, uygulama sürecinde sorumluluk ve hoşgörü değerlerini geliştirdiklerini, eleştirel düşünme, eleştiriye açıklık, kendini ifade etme, objektiflik ve bilgi ve iletişim teknolojileri kullanımı gibi beceri ve yeterliklerde de ilerleme kaydettiklerini aktarmışlardır.

Sürekli hafta hafta yüklediğimiz için belgelerimizi uygulamalarımızı oraya kendim için söyleyeyim bana sorumluluk duygusu da kazandırmış oldu aslında. Yani artık şey gibi hissetmeye başladım yapıyım sisteme yükleyeyim hazır olsun. Yani bana bir sorumluluk duygusu kazandirdl. (Ö1)

Bence şöyle bir şey oldu. Sinıf ortamında durduk yere biri ödevime yorum yapsa ben ters tepki verebilirim. Çünkü böyle bir şey talep etmiyorum. Fakat e-portfolyo ortamında yorum seçeneği olduğu için ve yorum gelebileceğini bildiğim için daha hoşgörülü davrandım gelen yorumlara. ...e-portfolyoya yüklediğimiz için ona yorumlar geleceğini bildiğimiz için ve biraz da sanal ortamda gecikmeli görebiliyoruz illa anında dönütte vermek zorunda değiliz bu noktada daha hoşgörülü yaklaşmamızı sağladı. (Ö2)

Benim öz eleş̧tiri yapmamı sağladı ve arkadaşlarımın çalışmalarıma yorum yapmasını benim dış eleştirilere açık olmama imkân sağladı. Mesela arkadaşlarım şurasını 
düzeltsen daha güzel olur ya da şurası farklı olabilir diye yazdığında bunları dikkate aldim. (Ö6)

Hocam objektiflik kazandırdı. Şöyle ki sınıfta daha iyi anlaştığımız arkadaşlarımız oluyor onları ödevlerini ister istemez olumlu yorumlama eğilimine gidiyoruz. Fakat bu daha sorumluluk gerektiren bir uygulama olduğu için tamamen her şeyden bağımsız her şeyi bir kenara birakarak gerçekliğiyle eleştirme bakış açısı sundu. (Ö8)

Elektronik portfolyo hazırlamak, teknik bilgi ve becerilerimi geliştirmenin yanı sıra bilgisayar bilgi ve becerimi de gösterdi ayrica dijital ortama ve yeniliklere ayak uydurmuş, teknolojiyi olumlu ve verimli kullanmış oldum. (Yansıtma Raporu - Ö7)

Süreç temelli değerlendirme, bireylerin sistematik bir biçimde sorumluluklarını yerine getirdiği ve bunların dersin yürütücüsü tarafindan belirli aralıklarla kontrol edildiği bir yapıdadır. Katılımcılar, bu yönünden dolayı e-portfolyo sürecinin kendilerini değerli hissetmelerini sağladığını sıklıkla ifade etmişlerdir. $\mathrm{Bu}$ durum, öğrencilerin derse ve değerlendirme sürecine olan bakış açılarını da olumlu yönde etkilemiştir.

Bize birebir dönütler yapılması kendimi değerli hissettirdi bana açıkçası. Not üzerinden dönütler yapılmaması benim çok hoşuma gitti çünkü ödev yüklüyoruz bekliyoruz acaba kaç alacă̆ız nasıl olacak ama birebir direkt dönütler yapılması benim hem derse olan ilgimi artırdı hem de zorunluluk olarak değil de zevkle sürdürdüm dersi. (Ö5)

Arkadaşımın dediği gibi derse geçmeden önce yaptığımız ödevler okunduğunda başta benim ismim vardı galiba ilk dersti galiba ilk benim ödevimi okunmuştu. Hiç bu zamana kadar üçüncü senemdi, ödevim okumamıştı. Açıkçası orada okunduğu zaman bana dönüt verildiğinde benim için çok önemliydi. (Ö10)

E-portfolyo sürecinde katılımcıların üzerinde durdukları bireysel faydalardan diğerleri kalıcı öğrenme, sınav kaygısını önleme ve iş yükünü azaltmaya yöneliktir. Katılımcılar, derste öğrendiklerini ara sinav ve y1l sonu sınavi yerine her hafta yerine getirmeleri gereken sorumluluklar kapsamında aktif tuttuklarından kalıcı öğrenmeler gerçekleştirdiklerini, sınav kaygısının ortadan kalktığını ve iş yüklerinin hafiflediğini belirtmişlerdir. Bu durum, klasik değerlendirmeler yerine süreçsel yaklaşımların kullanımının öğrencilerin akademik gelişimine daha olumlu yansıdığının önemli bir göstergesi şeklinde yorumlanabilir.

Derste işlediklerimiz vize haftasında toplu bir şekilde isteniyor ve bu beni çok zorluyor. Çünkü vize haftası olduğu için derslere ulaşmamız çok zor oluyor. Ben de aklımda tutmadığım için çok fazla zorlanıyorum. Devamlı arkadaşlarımı soruyorum, geçmişi hatırlamaya, notlar tutmaya çalışıyorum. E-portfolyo uygulamasında her hafta yaptığım için aklımda kallyor hem de taze dersler arasında üç dört gün olduğu için tüm bilgiler aklımda kalmış oluyor. (Ö9)

Ben e-portfolyo üzerinden hazırladı̆̆ım ödevlerin daha etkili ve kalıcı olduğunu düşünüyorum. Çünkü diğer derslerde sinav haftasında bir dersimiz yok birden çok dersimiz var ve yetiştirme sikıntımı oluyor o an aklımıza ne geldiyse o şekilde yazıyoruz. Etkili hazırladı̆̆ımı düşünmüyorum. Ama e-portfolyo üzerinde daha deneyim sahibi oluyoruz deneyimlerimizi daha iyi aktarma firsatını buluyoruz. Bu yönden bana büyük katkısı olduğunu düşünüyorum. (Ö3)

\subsection{Akran Etkileșimi}

E-portfolyo uygulaması sürecinde sosyal bilgiler öğretmen adayları Seesaw aracı üzerinden etkileşime girmişlerdir. İlk olarak, öğretmen adayları arkadaşlarının her hafta sisteme yükledikleri sorumluluklarını izlemişlerdir. $\mathrm{Bu}$ nedenle, araştırmada sıklıkla tekrarlanan kodlardan biri olarak akran izleme ortaya çıkmıştır. Katılımcılar, uygulama süreci boyunca birbirlerini Seesaw aracı üzerinden izlemişler ve kendi ödevlerini daha sağlıklı biçimlendirmişlerdir. Çünkü katılımcılar bazen sorumluluklarının detaylarını yanlış 
anlayabilmekte ya da istenilen düzeyde sorumluluğunu ortaya koymada sorun yaşayabilmektedirler. Akran izlemesi bu sorunu gidermede etkili çözümlerden biri olarak değerlendirilmektedir.

...birbirimizin ödevlerini görme imkânına sahip olduk, bu da benim açımdan çok verimli oldu. Çünkü şöyle bir detay var, ben bazen farklı düşündü̈̆̈̈m için ödevleri yanllş algllayabiliyorum. Biz ortak bir platformda birbirimizin ödevlerini gördüğ̈̈müz için arkadaşlarımın ödevlerinden görüp fikir aldığım oldu. (Ö1)

Benim açımdan düşündüğümde ödevi yüklüyordum. Daha sonra ödevimi beğenmiyordum o hafta. Sonra arkadaşlarımın ödevlerine bakıyordum. Arkadaşlarımın yaptığı daha dikkat çekici olabiliyordu ya da daha farklı bir açıdan baktıkları için benim görüş açımı da değişstirebiliyordu. (Ö4)

Yalnızca kendi çalışmalarımı değil arkadaşlarımın çalışmalarını da görebiliyor ve tek bir çalışma için çeşitli örneklere rahatllkla erişebiliyorum. Diğer derslerimizde sadece kendi çalışmalarımla sınırlı kaldı̆̆ım için belki de dersin kapsamını yeterince iyi kavrayamamış olabilirim. (Yansitma Raporu - Ö2)

Yaptığımız ödevleri birbirimiz ile gördüğümüz için çeşitli bakış açıları kazanabiliyoruz, başka bir uygulamada veya okulda bu imkânımız olmuyor olmadı̆̆ında sadece kendi yaptığımız ve kendi düşündüğ̈̈müz fikirlerle kalıyoruz, sınıfta bazı ödevler okunuluyor ama sadece sinırl kişilerde kaltyor bu uygulamada arkadaşlarımızın ödevlerini her zaman açıp okuyabiliriz. (Yansıtma Raporu - Ö8)

Öğrenci-öğrenci etkileşiminde dikkate değer eylemlerden biri akran dönütleridir. Her ne kadar dönütler dersin yürütücüsü tarafından sağlansa da öğrencilerin birbirlerini değerlendirmeleri de akademik gelişim sürecine katkı sunmaktadır. E-portfolyo uygulaması sürecinde de akranlar arası etkileşimin odağında akran dönütleri yer almaktadır. Sosyal bilgiler öğretmen adayları Seesaw aracı üzerinden birbirlerine yorum yapmışlar ve bu doğrultuda kendi ödevlerini düzenleme yoluna gitmişlerdir. Böylece hem ödevlere farklı bakış açıları yansıtılmış hem de öğretmen adayları farklı ödevleri değerlendirerek akademik bilgi konusundaki derinliklerini artırabilmişlerdir. Bu durum, öğrenci merkezli anlayışın sadece öğretim sürecine özgü olmadığının aynı zamanda ölçme ve değerlendirme sürecinde de hâkim k1lınabileceğinin önemli bir dayanağı olarak yorumlanabilir.

Birbirimize dönüt vermemiz gerçekten güzel bir şey. Mesela ben sürekli kararsız kalan biriyim. Yaptı̆̆ım ödevler hakkında arkadaşlarıma gösterip fikir almayı seven birisiyim. Tek tek arkadaşlarıma göstermektense oraya koyduğumda bütün arkadaşlarımın olumlu veya olumsuz yorum yapması benim çok yararıma oldu çünkü ödevlerimi o şekilde değiştirebilme imkânım olduğu için bazı ödevlerimi arkadaşlarımın yorumu üzerine değiştirmiştim. (Ö5)

Hem kendi eksikliklerimizi gördük bence hem de arkadaşlarımızın eksikliklerini gördük. Bunu da değerlendirerek hem yorumlarımıza yansittık hem de arkadaşlarımı bizim ödevlerimize yorum yaparak bizim eksikliklerimizi görmemizi sağladı. (Ö7)

Arkadaşlarımın ödevlerine yorum yapabilmem, onların bana yorum yapabilmesi herkese farklı bir bakış açısı kazandırıp yorumları dikkate alarak ödevleri yapma ve düzenleme firsatı sunuyor. (Yansitma Raporu- Ö9)

Sinıftaki ögrencilerin, arkadaşlarının ödevlerine erişmesi de Seesaw uygulamasını olumlu yanlarındandır. Ödevlerin yoruma açık olması diğer ögrrencilerin yorum yaparak ödevi yapan ögrencinin eksiklerini görmesine ve ödevi düzeltmesine olanak sağlamaktadır. (Yansitma Raporu - Ö3)

Akran dönütü vurgusu araştırmacı günlügünde de sıklıkla yer almıştır. Araştırmacılar, öğrencilerin akranlarını değerlendirirken titiz davrandıklarını belirtmektedir. 
Öğretmen adayları ödevlerini sisteme yükledikten sonra arkadaşlarının ödevlerine yorum yaptılar. Bu yorumlar incelendiğinde önemli eleştirilere de rastlandl. Böylece ögrencilerin birbirlerinin ödevlerini titiz bir biçimde incelediği görüldü. (Araştırmacı günlüğü 3. Hafta)

\section{3. Öğrenci-Akademisyen Etkileşimi}

Eğitimciler için öğrencilerin gelişimini izlemek önemli olmakla birlikte oldukça zor bir istemdir. Çünkü sınıf ortamında her öğrenciyi izleyip onların gelişimini kayıt altına alabilmek kısıtlı zaman nedeniyle neredeyse imkânsızdır. Fakat süreç temelli değerlendirmeler bu sorunun ölçme ve değerlendirme boyutunu çözmede etkili görünmektedir. Eğer süreç temelli ölçme ve değerlendirme çevrim içi ortamlarda gerçekleştiriliyorsa eğitimcilerin işi daha da kolaylaşmaktadır. Çünkü dijital araçlar yardımıyla öğrencilerin gelişimi daha kolay takip edilebilmekte ve hızlıca dönüt sağlanabilmektedir. Bu vurgu, sosyal bilgiler öğretmen adayları tarafından da desteklenmektedir. Katılımcılar, uygulama sürecinde ödevlerinin sorumlu akademisyen tarafından kolaylıkla izlenebildiğini ve kendilerine biçimlendirici dönütler verildiğini ifade etmişlerdir. Bu bulgu, e-portfolyo uygulamasının öğrencilerin akademik açıdan izlenmesinde ve öğrenmelerinin biçimlendirilmesinde etkili bir araç olduğu şeklinde yorumlanabilir.

Akademik gelişimi izleme incelenen durumda da önemli bir vurgu olarak ortaya çıkmıştır. Sosyal bilgiler öğretmen adayları, dersi yürüten akademisyenin izlemesi sayesinde kendilerini daha iyi tanıyabildiklerini vurgulamışlardır. Bunun haricinde akademik performansın yükselmesinde de izlemenin etkili olduğu görülmektedir.

...elektronik portfolyolarla hazırlanan şeyler daha kullanışlyydl. Ve biz her zaman çalıșmalarımızı yeteneklerimizi gösterme imkânı bulduk orada. Hocamız oraya girip baktığı zaman bizim hayal gücümüzü, düşüncelerimizi görebildi. (Ö1)

Gruptaki ögrencilerin e-portfolyolarının düzenli olarak incelenmesi dersin ve ögrenci performansinin daha verimli hale gelmesinde önemli bir rol oynadl. Özellikle ilk haftaki materyal ve raporlara ilişkin ögrenci performansinin ilerleyen haftalarda daha istenilen bir düzeye geldiği görüldü. Ögrenciyi izlemek hem onlar tanımak hem de akademik performans gelişimini takip etmek açısından etkili oldu. (Araştırmacı Günlüğü 9. Hafta)

Dönüt vermek yapılandırmacı eğitim anlayışının temel dinamiklerinden biridir. Öğrenci merkezli olarak kurgulanan öğrenme sürecinde öğrencinin akademik gelişimindeki eksiklikleri saptamak ve bunların öğrenci tarafından düzeltilmesini istemek öğretmenin önemli sorumluluklarından biridir. Bu araştırmada incelenen durum kapsamında dersin akademisyeni tarafından öğrencilere düzenli olarak dönütler verilmiștir. Sosyal bilgiler öğretmen adayları, eportfolyo üzerinden dönütlerle sürdürülen süreç hakkında verimlilik ve eksikliği tamamlama vurgusunda bulunmuşlardır. $\mathrm{Bu}$ sürecin bireysel akademik performanslarını olumlu yönde etkilediğinden söz etmişlerdir.

Hocam benim düzelmeme yol açtı açıkçast. Ben zaten bir ödev verildiğinde o ödevi verildikten sonra 2-3 gün içerisinde bitirmiş olurum. Ama burada şunu gördüm ögretmen bunu kontrol edecek sen daha iyisini yap daha güzelini yap bu şekilde ödevin daha iyi olacak daha güzel olacak bu şekilde bana dönüt verilmesi benim kendimi daha çok düzeltmeme yol açtt. (Ö1)

Hocam tarafindan değerlendirmelerin bana güzel etkiler kattı̆gın fark ettim. Ama ilk başta bu durum beni telaşlandırmıştı, strese girmiștim. Derslere girerken ne olacak, ne yaptım, ya kötü yaptıysam tarzı düşüncelere kapılmıştım. Ama sonradan bu durum daha iyi olduğunu diğer yaptı̆̆ım ödevlere göre daha iyi ödevler çıkardığımı düşündüm. (Ö10) 
Çevrim içi ortamda portfolyomun olması ve öğretim üyesi tarafindan düzenli olarak kontrol edilmesi çalışmalarımda etkili oldu. Biz her hafta ödevimizi yüklüyorduk hocamı bize dönüt sağllyor derslerde açlyorduk tek tek inceliyorduk. Bu güzeldi. Mesela hocamın bana dönüt sağladı̆̆ını bildiğim için daha dikkatli yapmaya, daha özen göstermeye çalıştım. (Ö5)

Öğretmenler, ögrencilerinin ödevlerine elektronik portfolyo üzerinden anında geri dönüş yapabiliyor. Elektronik portfolyo, bana göre bu konuda ögretmen, ögrenci ve veli için avantajl bir uygulama. Ögretmen, ögrencisinin öğrenme seviyesini ve ilerlemesini takip edebilir. (Yansitma Raporu - Ö4)

\subsection{Dijital Etkiler}

İncelenen durum kapsamında e-portfolyo uygulamasının sosyal bilgiler öğretmen adaylarına birçok teknolojik fayda sağladığına ulaşılmıştır. Katılımcılar, özellikle depolama ve koruma, erişim, ürünü düzenleme ve maliyet azaltma özelliklerine yoğun vurgular yapmışlardır. Bu bulgu, e-portfolyo sürecinin akademik gelişimin yanında katılımcılara dijital dünyanın firsatlarından da yararlanma olană̆ı sunduğunun önemli bir göstergesidir.

Sosyal bilgiler öğretmen adaylarının lisans öğreniminde ölçme ve değerlendirme noktasında yaşadıkları önemli sorunların başında birçok dersin ödevlerini saklamakta güçlük çekmeleri ve ödevlerinin yıpranmasından endişelenmeleri gelmektedir. Katılımcılar, eportfolyo sayesinde bu sorunların aşıldığını vurgulamışlardır. E-portfolyo süreci çevrim içi ortamda yürütüldüğünden katılımcıların ürünlerinin depolanmasında ve korunmasında herhangi bir sorun yaşanmamıştır. Böylelikle katılımcıların endişelerinin çevrim içi ortamın özellikleri sayesinde giderildiği söylenebilir.

Yani hafta hafta yükledik ve böyle bilgilerimizin bir yerde sabit bir şekilde kalması bizim için daha yararlı oldu. Çünkü geçmişe dönük bir bilgiye ulaşmak istediğimiz zaman oradan hemen ulaşabildik, öbür türlü olsa belki dosyalarımıza ulaşamayabilirdik. Kaybedebilirdik. Öncelikle ben de tüm derslerimde yaptı̆̆ım ödevleri aldı̆̆ım notlart uzaktan eğitime geçtiğimizden beri bilgisayarda depolamaya çalışlyorum. Fakat malum, bilgisayarım on bir yıllık bir bilgisayar olduğu için bazen çökmeler yaşanabiliyor ve dosyalarımı yedeklemediysem dosyalarım tamamen çöp oluyor. Fakat Seesaw'a yüklediğimiz belgelerin hepsi orada duruyor ve muhtemelen sonsuza kadar kalacaklar. (Ö2)

Ortaokul zamanlarımızdan bu yana performans ödevlerimizi hep klasörde biriktiriyorduk. Bu nedenle belli bir süre sonra ödevlerimizde yıpranmalar meydana geliyordu. Ylprandiğg zamanda tekrar ödevimizi kolay bir şekilde düzenleyemiyorduk. $\mathrm{Ya}$ da istediğimiz zaman basit bir şekilde ödevimize eklemeler ve çıkarmalar yapamıyorduk. Arkadaşımızın da dediği gibi bilgisayarda Google Drive'a yüklemezsek bilgisayarımı bozulduğunda ya da format atıldığında kayboluyordu yani depolama açısından zorluk yaşlyorduk. Dijital portfolyo harika bir uygulamaydı. (Ö8)

Dersimizin ilk haftasindan beri verilen ödevleri hep elektronik portfolyoma ekledim. Bu sayede bütün çallşmalarım düzenli ve toplu halde bir arada duruyor. Üstelik kaybolur, yırtılır derdi de yok çünkü bilgisayartm veya telefonum bozulsa bile dijital bir ortamda dönem boyunca yaptı̆̆ım çalışmaları güvenli bir şekilde saklayabiliyor ve daha sonrasında ulaşabiliyorum. (Yansıtma Raporu - Ö9)

Açıkça söylemem gerekirse ilk haftalarda kullandığımda alışma aşaması olduğu için mi nedense sürece hep bir önyargı ile baktım. Ama süreç ilerledikçe gördüm ki ayrı ayrı dosyalarda saklamamı bile mümkün olmayan, belli bir süre geçtikten sonra silip geçtiğimiz bütün dosyalarımızı burada bir arada toplamakla beraber uzun vadede saklamamız mümkün. (Yansitma Raporu - Ö10) 
Araştırmacı günlüğünde de depolama ve koruma üzerine önemli vurgulara rastlanmıştır. Öğretmen adaylarının haftalık ders değerlendirmesinde bu önemli dijital etkiye sıklıkla vurgu yaptıklarına ulaşılmıştır.

$\mathrm{Bu}$ hafta öğretmen adaylarının üzerinde durduklarl nokta depolama ile ilgiliydi. Öğretmen adayları özellikle geleneksel portfolyonun dayanıksılı̆̆ından şikâyet ettiler. Bunun aksine, e-portfolyonun tüm materyalleri depoladiğın ve dijital olmasindan dolayı zarar görme riskini ortadan kaldırdı̆̆ını söylediler. (Araştırmacı Günlüğü 5. Hafta)

Katılımcıların üzerinde durdukları diğer bir dijital etki, ürüne erişim üzerinedir. Neredeyse tüm eğitim kademelerindeki öğrencilerin yaşadıkları gibi lisans öğrencileri de hazırladıkları portfolyo ile bazen aynı mekânda olamamaktadırlar. Bu durum, onların ürünlerine erişimlerinde önemli bir engel oluşturmaktadır. Örneğin, portfolyoya bir ürün eklenmesi ya da bir üründe düzenleme yapılması gerektiğinde mekân sorunu büyük bir engel olarak karşımıza çıkmaktadır. İncelenen durumda e-portfolyo uygulamasının çevrim içi ortamda yürütülmesinden dolayı ürüne erişim sorununun ortadan kalktığı vurgulanmıştır. Katılımcılar, istekleri zaman diliminde ürünlerine erişim sağlayabilmelerinin oldukça önemli bir fayda olduğunu ifade etmişlerdir.

Hocam ben taşıma konusuna değinmek istiyorum. Online tasarladiğımız ürünlerimiz her an her zaman elimizin altında ve ulaşılabilirken diğer portfolyo ürünlerini taşımak sikıntıllydı hocam her yere saklamak konusu özellikle. Ama e-portfolyoya yüklediğimiz zaman internetin olduğu her yerde ulaşım sağlayabiliyoruz. (Ö8)

Bir de hepimiz öğrenci olduğumuz için ve sıkış tepiş dolmuşlarda geldiğimiz için taşıma anlamında bunlar sıkıntı yaşatırken e-portfolyo için herhangi bir taşıma yani flashbelleğe atabiliriz, Google Drive'a yükleyebiliriz. Zaten e-portfolyoda orada duracak orada istediğimiz zaman hesaba giriş yaparak telefondan veya bilgisayardan herhangi bir akıllı cihazdan ve internetin olduğu ortamdan hesaba giriş yaparak taşıma dersinden kurtulmuş oluyoruz. (Ö2)

Bana göre en avantaj sağlayan yönü her an elimin altında olmaslydl. Çünkü istediğin zaman ulaşabilmek büyük bir avantaj bence. (Ö5)

Bu uygulama bilgisayar ve telefondan rahatllkla kullanılabilmektedir. Erişimi dijital ortamdan sağlanmaktadır. Ĕgitimde bu tür uygulamaların yayginlaşmast hem ögretmenler hem ögrenciler acısından olumlu sonuçları olacaktır. (Yansitma Raporu Ö5)

Ders içi değerlendirmede özellikle erişim özelliği üzerinde duruldu. Öğretmen adayları, geleneksel portfolyo kullanımında ürünlerinin farklı bir mekânda kalabileceğini ve erişemeyeceklerini vurguladılar. E-portfolyoda ise internet bağlantısının olduğu her yerden 7/24 portfolyolarına ulaşabildiklerini ifade ettiler. (Araştırmacı Günlüğü 6 . Hafta)

Katılımcıların e-portfolyonun dijital faydası olarak nitelendirdikleri diğer vurgular ürünü düzenleme ve maliyet üzerine gerçekleşmiştir. Basılı materyaller ya da ödevler uzun uğraşlar sonucu hazırlanıp çıktıları alınarak portfolyo dosyalarına eklenmektedir. Fakat bunlar kontrol edildiğinde düzenleme istekleri belirebilmektedir. $\mathrm{Bu}$ durum da öğrencinin fazladan uğraş vermesi ve maliyet yüklenmesi anlamına gelmektedir. İncelenen durumda da sosyal bilgiler öğretmen adayları ürünü düzenleme ve maliyet üzerine vurgu yapmış hatta bu iki özelliğin birbiriyle oldukça ilişkili olduğunu belirtmişlerdir. Katılımcılar, e-portfolyo uygulama sürecinde ürünlerini daha kolay düzenleyebildiklerini ve maliyet açısından önemli tasarruf sağladıklarını söylemişlerdir. Bu bulgu, çevrim içi ortamda sürdürülen portfolyo uygulamalarının öğrencinin hem iş yüküne hem de bütçesine olumlu bir etkide bulunduğu şeklinde yorumlanabilir. 
Ödevi bu sisteme yüklüyoruz. Öğretmen ödevi takip ettiğinde öğretmen dönüt verdiğinde ögrrenci ödev üzerinde bir daha uğraşabiliyor. O ödevi oradan silmeden uğraşabiliyor tekrar kaldırabiliyor taslak olarak kullanabiliyor yani. Taslağını geliştirebiliyor. Öğretmen bir daha dönüt verebiliyor arkadaşları dönüt verebiliyor. Taslağına bir şeyler daha ekleyebiliyor. Öğrencinin birçok açıdan farklı farklı uygulamaları tek bir platform üzerinde oluşturma imkânı sağllyor. Ve bunu yaparken de hiç para harcamıyor. (Ö3)

...yaptığımız ödevleri elimde kartonla götürdüğümü düşünüyorum karda kışta yağmurda çok zorlanıyorduk ya da ödevi yaparken bir yerini yanlışlıkla kestik o ödev iptal oluyordu tekrar bir karton alıp yapmak zorunda kallyorduk ama şimdi artı eportfolyolar sayesinde yaptığımız hataları tekrar düzeltebilme imkânımı var. İstediğimiz kadar baştan yapma imkânımız var ve de artık teknoloji çă̆ındayız çağın gerisinde kalmamak için de mecbur bu portfolyolardan yararlanacă̆ız. (Ö9)

\subsection{Sorunlar}

E-portfolyo kullanım sürecinde sosyal bilgiler öğretmen adayları tarafından her ne kadar olumlu yönler baskın bir biçimde dile getirilmiş olsa da süreçte bazı sorunların yaşandığı da tespit edilmiştir. Katılımcılar tarafından dile getirilen sorunların nedenleri incelendiğinde, bunların ya birey özelliklerinden ya da teknoloji kaynaklı olarak ortaya çıtığı görülmüştür. Burada dikkat edilmesi gereken nokta, katılımcılar tarafından e-portfolyo uygulamasının özüne yönelik herhangi bir sorunun belirtilmemesidir. Bu bulgu, kullanılan Web 2.0 aracı kaynaklı ya da bireysel yeterlikten türeyen sorunlar ortaya çıksa da katılımcıların ölçme ve değerlendirmelerinde kullanılan e-portfolyo değerlendirmesinden memnun olduklarının önemli bir göstergesidir.

Katılımcıların süreçte karşılaştıkları sorunlara ilişkin görüşleri incelendiğinde, en büyük problemin teknoloji temelli olduğuna ulaşılmıştır. Katılımcılar, özellikle internet bağlantısının olmayışını ya da internet bağlantısının kopmasının sürecin verimini düşürdüğünü ifade etmişlerdir.

Negatif yönü de şu hocam internet problemi. Bu da zaten ülkemizin genel problemi, onun haricinde hiçbir şekilde ben kendi üzerimde aşırı sıkıcı bir davranış görmedim. (Ö10)

Genel olarak en büyük problemimiz internet bağlantısı çünkü bazı yerlerde internet erişimi olmayan çoğu ögrenci olabilir. Mesela köylerde bu platformlar internet olmadiğı zamanlarda çok aktif bir şekilde kullanılamıyor. (Ö4)

Bir de maalesef internet problemi var, tabi ki ortaokul ve lise ögrencilerinin interneti olmayabiliyor. Köylerde yaşayan insanlar, ilçelerde yaşayan insanlar olabiliyor veya şehir merkezinde de internet bağlantılarl geçmediği için evine internet bağlatamayanlar hani bağlatabilme imkânı varken şehir yetersizliğinden dolayı bağlatamayanlar da oluyor. (Ö3)

Bu uygulamanin dezavantajlarından bahsedecek olursam maalesef ki herkesin internet ve bilgisayar imkânı bulunmuyor. Bu bakımdan bu uygulamaların kullanılmasında büyük bir sorun olduğunu düşünüyorum. (Yansitma Raporu - Ö1)

İnternet bağlantısının yanı sıra katılımcılar tarafindan teknolojik donanımdan kaynaklanan aksaklıklar, e-portfolyo sistemine dosya yüklemede karşılaşılan sorunlar ve uygulamaya çoklu girişteki güçlükler de dile getirilen diğer aksaklıklardır. Bu sorunların kaynağına bakıldığında e-portfolyo sürecinde kullanılan uygulamadan ya da kişisel cihazdan kaynaklandığ 1 görülmektedir.

Dosya yükleme formatında hem ben hem de diğer arkadaşlarım çok sorun yaşadık çünkü ödevimizi Word yazmıştık ama Word yükleyemedik. Bu yüzden sonra sistemi 
kurcalamaya çalıştık sonra biri PDF olarak yüklenebildiğini keş̧fetti. Hepimiz tekrardan $P D F$ şeklinde yükledik. (Ö2)

Seesaw'un şu özelliği kötüydü Word türünde yükleyemiyorduk. O yüzden her Word'ü pdf yapmamı gerekiyordu yükleyebilmemiz için bu kötüydü. Yani direkt görsel ve pdf yükleme var fakat Word yoktu. O kötüydü onun dışında hiçbir problem olduğunu düşünmüyorum. (Ö7)

Hocam ben kişisel olarak teknolojik aksaklıklar yaşamıştım bilgisayarım bozulmuştu. $O$ hafta derse katılamamıştım sonrasında arkadaşlarımın yardımıyla ögrrenmeye çalışmıştım ama çok zorlandım hangi uygulamaydı hatırlamıyorum ama telefondan hazırlarken çok zorlamıştım. (Ö10)

Hocam çoklu giriş desteğini belirtebilirim. Günümüzde iki üç cihazdan bir yere bağlanabiliyorsak buna da bağlanalım diye düşünüyorum. (Ö6)

İncelenen durum kapsamında beliren sorunların bir kısmı da bireysel özelliklerden dolayı ortaya çıkmıştır. Bu noktada, katılımcıların teknoloji okuryazarlıkları ve yabancı dil bilgisi yeterlikleri sorunun kaynağı olarak görülmektedir. Katılımcılar, e-portfolyo oluşturma sürecinde bireysel özelliklerinin süreçte birer engel olarak karşılarına çıktığını ifade etmişlerdir.

Aslinda buna teknolojik yetersizlik denilebilir. Teknoloji konusunda yeterli bilgi birikimine sahip olmadiğım için hocam genel olarak sistemi çözmekte zorluk çektim. (Ö1)

Illk başta söylediğim gibi hocam benim teknolojiyle aram iyi olmadı̆̆ için biraz ön yargıll yaklaştım uygulamalara ilk haftalarda. Dedim nasıl olacak, bu daha farklıymış diye düşündüm hep. (Ö3)

Arkadaşımı değinmişti ama bir daha değinmekte yarar var. Dezavantaj olarak Türkçe dil desteğinin yetersiz olmasinı söyleyebilirim. (Ö4)

Dersin başında yönlendirilmeseydik ben elektronik portfolyonun nasıl kullanılacağını asla çözemezdim. Yani buna ne dil bilgim yeterli, ne de teknoloji bilgim yeterli. (Ö5)

\section{TARTISYMA, SONUÇ VE ÖNERILLER}

$\mathrm{Bu}$ araştırmada sosyal bilgiler öğretmen adaylarının e-portfolyo sürecine ilişkin deneyimleri incelenmiştir. Katılımcıların deneyimlerini ortaya çıkarmada 10 hafta süren eportfolyo kullanım süreci merkeze alınmıştır. Araştırma verileri süreç devam ederken ve süreç sonunda toplanmıştır. Toplanan veriler nitel içerik analiziyle çözümlenmiş ve katılımcıların deneyimleri ortaya çıkarılmıştır. Araştırma sonucunda, e-portfolyo kullanımının sosyal bilgiler öğretmen adaylarına birçok kişisel fayda sağladığına, akran etkileşimini etkili hale getirdiğine, akademisyen-öğrenci etkileşimini derinleştirdiğine, çevrim içi ortam kullanımından dolayı dijital açıdan kolaylıklar sağladığına ve süreçte de hem birey kaynaklı hem de teknoloji kaynaklı sorunlar belirdiğine ulaşılmıştır. Araştırmanın bu bölümünde araştırma bulguları alan yazın kapsamında tartışılacak olup çıkarımlar gerçekleştirilecek, sınırlılık ve önerilerden söz edilecektir.

Araştırma kapsamında e-portfolyo sürecinin sosyal bilgiler öğretmen adaylarına birçok kişisel fayda sağladığı sonucuna ulaşılmıştır. Bunlardan ilki e-portfolyo kullanımının sosyal bilgiler öğretmen adaylarının akademik öz düzenleme becerilerini geliştirmesi üzerinedir. Alanyazında bu sonucu destekleyen birçok araştırma vardır (Akgün ve Şahin Kölemen, 2020; Alexiou ve Paraskeva, 2010; Erdoğan, 2006; Güven ve Aydoğdu, 2009; Mihladız, 2007). Bu sonucun bir nedeni olarak, öğrencilerin kendi öğrenmelerinden sorumlu olmaları ve ürünlerine ilişkin yansıtmalar yapmaları gösterilebilir (Karakuş, 2008). E-portfolyo sürecinin sosyal 
bilgiler öğretmen adaylarına sağladığı bir diğer kişisel faydanın beceri, değer ve yeterlilik kazanımı biçiminde olduğuna ulaşılmıştır. Bu beceri, değer ve yeterlilikler; sorumluluk ve hoşgörü değerleri, eleştirel düşünme, eleştiriye açıklık, kendini ifade etme, objektiflik ve bilgi ve iletişim teknolojileri kullanımı olarak ifade edilebilir. E-portfolyo sürecinin özellikle bilgi ve iletişim teknolojileri kullanımı beceri ve yeterliliklerini geliştirdiğine ilişkin birçok araştırma vardır (Gömleksiz ve Koç, 2010; Lin, 2008; Heath, 2005; Özyeginer, 2016). Lorenzo ve Itelson (2005) e-portfolyo kullanımının eleştirel düşünme becerisinin yanı sıra iletişim, düşünceleri sentezleme, stratejik planlama, problem çözme, öz yansıtma gibi becerileri kazandırdığını vurgulamaktadır.

Araştırmada elde edilen bulgular doğrultusunda, e-porfolyo kullanımının sosyal bilgiler öğretmen adaylarının zamanı verimli kullanmalarına katkı sağladığı sonucuna ulaşılmıştır. Ancak e-portfolyo oluşturmanın ve arşivlemenin zaman alıcı olduğuna ilişkin araştırmalar da vardır (Barış ve Tosun, 2013; Erten, 2015; Gök, Baş ve Ayaz, 2020). Barış ve Tosun (2013) tarafından yapılan araştırmada öğrenciler e-portfolyo destekli öğretim sürecinin sonunda olumlu tutuma sahip olsalar da e-portfolyo sürecinin olumsuz bir yönü olarak zaman alıc1 olduğunu ifade etmiş̧lerdir. Struvyen, Blieck ve Roeck (2014) öğrencilerin yeterli dönüt alamadıkları için e-portfolyo kullanımını zaman kaybı olarak gördüklerini ifade etmişlerdir. Araştırma kapsamında e-portfolyo sürecinin katılımcıların kendilerini değerli hissetmelerine katkı sağladığı sonucuna ulaşılmıştır. Benzer bir sonuca Gürol ve Demirli'nin (2006) çalışmasında da ulaşılmıştır. Araştırmacılar çalışmaları sonucunda, katılımcıların saygı gördükleri ve bir öğrenen olarak kendilerini önemli hissettiklerini belirtmişlerdir. Bu sonuç, öğretimle birlikte yürütülen değerlendirme sürecinde işbirlikli bir yaklaşımla güç ve kontrol paylaşımının yapılmasıyla açıklanabilir (Anderson, 1998).

E-portfolyo kullanımının katılımcılara kalıcı öğrenme, sınav kaygısı önleme ve iş yükü azaltmaya yönelik bireysel faydalar sağladığına da araştırma sonucunda ulaşılmıştır. Eportfolyo kullanımın kalıcı öğrenmeye katkı sağladığına ilişkin benzer çalışmalar vardır (Corwin, 2003; Erten, 2015; Hewett, 2004; Milman ve Kilbane, 2005; Özgür, 2016). Ülker, Ünlü ve Usta'nın (2021) çalışmasında ise öğrenciler e-portfolyo sürecinde anında dönütlerle konunun pekiştirildiği için anlamlı ögrenmenin sağlandığını ifade etmişlerdir. Barış ve Tosun (2013), öğrencilerin sınav kaygısı düşük bir ölçme ve değerlendirme sürecinden geçmelerinin e-portfolyo kullanımına yönelik olumlu yönde fikirler geliştirmelerini sağladığını belirtmişlerdir. Bunun nedeni olarak öğrencilerin değerlendirme sürecine katılımlarıyla özgüvenlerinin artması ve not korkularının ortadan kaldırılması gösterilebilir (Özyeginer, 2016).

Araştırmada elde edilen bulgular doğrultusunda, sosyal bilgiler öğretmen adaylarının eportfolyo sürecinde akran etkileşimi sayesinde ödevlerindeki eksiklikleri giderdikleri, farklı bakış açılarını ödevlerine yansıttıkları ve akademik bilgilerini derinleştirdikleri sonuçlarına ulaşılmıştır. Benzer şekilde, Gennip ve diğerleri (2009) de nitelikli akran geri bildirimi alan öğrencilerin daha az nitelikli akran geri bildirimi alan öğrencilere göre daha fazla öğrenme avantajı elde ettiği sonucuna ulaşmıştır. Ngui, Pang ve Hiew (2020) ise öğrencilerin büyük bir çoğunluğunun akranlarından gelen geri bildirimi faydalı bulmasına rağmen bazı öğrencilerin bu geri bildirimleri objektif bulmadığını belirtmişlerdir. Bu durumun ortaya çıkmasındaki neden, yapılan değerlendirmenin puanlayıcıdan puanlayıcıya farklılık göstermesidir. Öğrenci performansının belirlenmesi sürecinde puanlayıcıların etkisinin dikkate alınması, ölçümlerin ve bu ölçümlere dayalı çıkarımların geçerlik ve güvenirliğine katkı sağlayacaktır (Şata ve Karakaya, 2020). Nicolaidou (2013) ise öğrencilerin e-portfolyo kullanarak zaman içinde daha kapsamlı akran geri bildirimi sağladıklarını ve akranlarının hatalarını belirleme ve düzeltilmesine ilişkin geri bildirim sağlamada giderek daha yetenekli hale geldikleri sonucuna ulaşmıştır.

E-portfolyo sürecinde öğrenci ile akademisyen arasındaki etkileşimin öğrencilerin akademik açıdan izlenmesinde ve biçimlendirilmesinde etkili bir araç olduğu araştırma 
kapsamında ulaşılan bir başka sonuçtur. Bu sonucu destekleyen bir araştırma Birgin (2008) tarafından gerçekleştirilmiştir. Araştırmada e-portfolyonun öğretmen ve öğrenci arasındaki etkileşimi güçlendirdiği, öğretmenlerin öğrenciyi daha iyi tanıyıp öğretimi biçimlendirme imkânı sağladığı sonuçlarına ulaşılmıştır. Benzer şekilde, Ülker, Ünlü ve Usta'nın (2021) çalışmasında da öğretmen ve öğrenciler e-portfolyonun, etkileşimi ve öğrencilerin takip edilmesini kolaylaştırdığını ifade etmiş̧lerdir. Peter, Nobye ve Rizhaugt (2012) çalışmalarında eğitmenlerin daha fazla geri bildirim ve yönlendirme yaparak rehber olmalarının e-portfolyoyu daha anlamlı hale getireceği sonucuna ulaşmışlardır. Böylece öğrenciye sağlanan geri bildirim ile düzeltme isteği gönderilecek, öğrencilerin düzenlemeleri gerçekleştirip ürünlerini portfolyolarına eklemeleriyle de sağlıklı bir etkileşim ortaya çıkacaktır. E-portfolyonun yalnızca dijital depolama alanı olarak değil, aynı zamanda etkili bir araç olarak kullanılması için eğitmenlerin e-portfolyo kullanımına ilişkin yeterli bilgi ve beceriye sahip olması, geri bildirim ve destek sağlaması gerekmektedir (Ngui, Pang ve Hiew, 2020).

Araştırma bulguları incelendiğinde, sosyal bilgiler öğretmen adaylarının e-portfolyo kullanımının; ürünleri depolama ve saklama, düzenleme, ürünlerine erişim ve maliyeti azaltma konusunda fayda sağladığı sonuçlarına ulaşılmıştır. Bu sonucu destekleyen birçok araştırma bulunmaktadır (Aktay ve Gültekin, 2014; Driessen ve diğerleri, 2007; Kim, 2001). Aktay ve Gültekin (2014) tarafindan yapılan araştırmada katılımcıların e-portfolyoyu saklama kolaylığından dolayı geleneksel portfolyodan üstün gördükleri ortaya çıkmıştır. Drissen ve dieğrleri (2007) de öğrencilerin portfolyolarına erişmek için ev ve okul arasında taşımaları gerekmediği öğrencilere e-portfolyonun kolaylık sağladığını ifade etmiştir.

Araştırma kapsamında sosyal bilgiler öğretmen adaylarının e-portfolyo sürecinde birey ve teknoloji kaynaklı sorunlar yaşadıkları ancak e-portfolyo kullanımının özüne yönelik bir sorun yaşamadıkları sonucuna ulaşılmıştır. $\mathrm{Bu}$ sonucu destekleyen birçok araştırma bulunmaktadır (Aktay ve Gültekin, 2014; Barış ve Tosun, 2014; Erten, 2015; Kabilan ve Khan, 2011; Totter ve Wyss, 2019). Jaekel (2020) tarafından yapılan araştırmada eportfolyonun önemli bir özelliği olan akran değerlendirme sürecinde öğrenciler arkadaşlarıyla ödevlerini inceleyip kendi ödevleriyle karşılaştırdıklarında not endişesi yaşadıklarını ifade etmişlerdir. Zeybek (2019)'in çalışmasında da benzer bir şekilde öğrenciler daha önce öz değerlendirme ve akran değerlendirme yapmadıkları için sürecinde başında zorlandıklarını ifade etmişlerdir. Milman ve Kilbane (2005) ise e-portfolyoların hazırlanmasında yaşananların öğrencilerin bireysel gelişimine katkı sağladığı ve sürekli gelişimleri için bir geçiş oluşturduğunu belirtmişlerdir.

Sosyal bilgiler öğretmenlerinin e-portfolyo kullanımına yönelik deneyimlerinin incelendiği bu araştırmada önemli sonuçlara ulaşılmasına rağmen araştırmada bazı temel sinırlılıklar da bulunmaktadır. İlk olarak, bu araştırmada çalışma grubu on kişiden oluşmaktadır. Bu sınırlılık, daha geniş çalışma gruplarıyla çalışılıp ortadan kaldırılabilir. Buna ek olarak, araştırma tekli durum desenindedir. Çoklu durum deseni belirlenerek farklı durumları birbiriyle karşılaştıran araştırmalar yürütülebilir. Araştırma sürecinde e-portfolyo kullanımı ile ilgili bazı sorunlara ulaşılmasına rağmen durum çalışması gereği çalışma grubuna herhangi bir müdahalede bulunulmamıştır. $\mathrm{Bu}$ sorunu ortadan kaldırmak için farklı araştırmalar incelenip ortak sorunsal noktalar tespit edilerek eylem araştırmaları tasarlanabilir. Son olarak, araştırmanın çalışma grubunda lisans öğrencileri yer almaktadır. Farklı eğitim kademelerinde de e-portfolyo kullanımına yönelik durum çalışmaları tasarlanarak öğrenci deneyimleri ortaya çıkarılabilir.

\section{KAYNAKÇA}

Akçıl, U., \& Arap, İ. (2009). The opinions of education faculty students on learning processes involving e-portfolios. Procedia-Social and Behavioral Sciences, 1(1), 395-400. 
Akgün, E. ve Kölemen, C. Ş. (2020). E-portfolyo oluşturmanın öğrencinin akademik öz düzenleme becerisine etkisi. Milli Eğitim Dergisi, 49(227), 117-140.

Aktay, S. ve Gültekin, M. (2014). İlköğretimde webfolyo uygulamas1: Öğretmen ve öğrenci görüşleri. İlköğretim Online, 13(3), 806-819.

Alexiou, A. ve Paraskeva, F. (2010). Enhancing self-regulated learning skills through the implementation of an e-portfolio tool. Procedia-Social and Behavioral Sciences, 2(2), 3048-3054.

Anagün, Ş. S., Atalay, N., \& Kandemir, C. M. (2018). E-Portfolio implementation experiences of prospective primary school teachers. Turkish Online Journal of Qualitative Inquiry, 9(2), 102-124.

Anderson, R. S. (1998). Why talk about different ways to grade? The shift from traditional assessment to alternative assessment. New Directions for Teaching and Learning, 74, 516.

Atılgan, H. (2019). Değerlendirme ve not verme. H. Atılgan (Ed.), Eğitimde ölçme ve değerlendirme (s. 315-367) içinde. Ankara: Anı Yayıncılık.

Barış, M. F. ve Tosun, N. (2013). Sosyal ağ ve e-portfolyo entegrasyonu: Facebook örneği. Ĕgitim ve Öğretim Araştırmaları Dergisi, 2(2), 122-129.

Barrett, H. C. (2000). Create your own electronic portfolio. Learning and Leading with Technology, 27(7), 14-21.

Birgin, O. (2008). Alternatif bir değerlendirme yöntemi olarak portfolyo değerlendirme uygulamasına ilişkin öğrenci görüşleri. Türk Eğitim Bilimleri Dergisi, 6(1), 1-24.

Butler, P. (2006). A review of the literature on portfolios and electronic portfolios. Erişim adresi:https://www.researchgate.net/publication/239603203_A_Review_Of_The_Literatu re_On_Portfolios_And_Electronic_Portfolios

Chantanarungpak, K. (2015). Using e-portfolio on social media. Procedia-Social and Behavioral Sciences, 186, 1275-1281.

Chou, C. M. (2012). Influence of teachers' perceived e-portfolio acceptance on teacher evaluation effectiveness in taiwan. Australasian Journal of Educational Technology, 28(4), 719-739.

Cochran Smith, M., \& Lytle, S. L. (1993). Inside outside: Teacher research and knowledge. New York: Teacher College.

Corwin, T. (2003). Electronic portfolios. Campus-wide information systems. Erişim adresi: https://www.emerald.com/insight/content/doi/10.1108/10650740310455586/full/html

Çepni, S. (2015). Performansların değerlendirilmesi. E. Karip (Ed.), Ölçme ve değerlendirme (s. 233-292) içinde. Ankara: Pegem Akademi.

Çukurbaşı, B. ve Kıyıcı, M. (2018). Öğretmen adaylarının öğretimde internet teknolojilerini kullanmaya yönelik tercihlerindeki değişimin incelenmesi. Kastamonu Ĕ̆itim Dergisi, 26(3), 765-776.

Demirezen, S. ve Keleş, H. (2020). Sosyal bilgiler öğretmenlerinin teknopedagojik alan bilgisi yeterliliklerinin çeşitli değişkenlere göre incelenmesi. Uluslararası Sosyal Bilgilerde Yeni Yaklaşımlar Dergisi (IJONASS), 4(1), 131-150.

Demirli, C., \& Gürol, M. (2007). An overview of the electronic portfolio process. E-Journal of New World Sciences Academy, 2(3), 254-271. 
Doğan, N. (2019). Temel kavramlar. N. Doğan (Ed.), Ĕgitimde ölçme ve değerlendirme (s. 228) içinde. Ankara:Pegem Akademi.

Driessen, E., Van Tartwijk, J., Van Der Vleuten, C., \& Wass, V. (2007). Portfolios in medical education: Why do they meet with mixed success? A systematic review. Medical Education, 41(12), 1224-1233.

Erdoğan, T. (2006). Yabancı dil öğretiminde portfolyoya dayalı değerlendirmenin öğrenci başarısı ve derse yönelik tutumlarına etkisi. (Yayınlanmamış Yüksek lisans Tezi). Dokuz Eylül Üniversitesi Eğitim Bilimleri Enstitüsü. İzmir.

Erten, P. (2015). Çevrimiçi işbirlikli öğrenme ortamında e-portfolyo uygulamasının akademik başarıya, tutumlara, motivasyona ve kalıcılığa etkisi. (Yayınlanmamış Doktora Tezi). Fırat Üniversitesi Eğitim Bilimleri Enstitüsü. Elazığ.

Fraenkel, J. R., Wallen, N. E., \& Hyun, H. H. (2012). How to design and evaluate research in education. New York: McGraw-Hill.

Gennip, N. A., Segers, M. S., \& Tillema, H. H. (2009). Peer assessment for learning from a social perspective: The influence of interpersonal variables and structural features. Educational Research Review, 4(1), 41-54.

Gilman, D. A., Andrew, R., \& Rafferty, C. D. ( 1995). Making assessment a meaningful part of instruction. NASSP (National Association of Secondmy School Principals) Bulletin, 79(573), 20-24.

Glesne, C. (2015). Nitel araştırmaya giriş̧ (Çev. Ed. A. Ersoy, P. Yalçınoğlu). Ankara: Anı Yayınc1lı.

Gomez, E. (2000). Assessment portfolios: Including English language learners in large-scale assessments. ERIC Digest. Erişim adresi: https://files.eric.ed.gov/fulltext/ED447725.pdf

Gök, B., Baş, Ö. ve Ayaz, M., (2020). Sınıf öğretmenlerinin e-portfolyo hakkındaki görüşleri. İnönü Üniversitesi Eğitim Fakültesi Dergisi, 21(2), 1085-1104.

Gömleksiz, M. N. ve Koç, A. (2010). Bilgisayar okuryazarlığ becerisi ediniminde e-portfolyo sürecinin öğrenen performansına ve tutumlarına etkisi. Erzincan Üniversitesi Eğitim Fakültesi Dergisi, 12(2), 75-96.

Grace, M. (1993). Implementing a portfolio system in your classroom. Reading Today, 10(61), 26-27.

Gülbahar, Y. ve Köse, F. (2006). Öğretmen adaylarının değerlendirme için elektronik portfolyo kullanımına ilişkin görüşleri. Ankara Üniversitesi Eğitim Bilimleri Fakültesi Dergisi, 39(2), 75-93.

Güler, N. (2020). Eğitim sürecinde hedef davranışlar ve hedef davranışların ölçülmesi. S. Tekindal (Ed.), Eğitimde ölçme ve değerlendirme (s. 280-323) içinde. Ankara: Pegem Akademi.

Gürol, M. ve Demirli, C. (2006, Nisan). E-portfolio sürecinde öğrenci motivasyonu. VI Uluslararası Eğitim Teknolojileri Konferansında sunulan sözlü bildiri, Gazimağusa.

Güven, E. ve Aydoğdu, M. (2009). Portfolyonun 6. sınıf fen ve teknoloji dersi vücudumuzda sistemler ünitesi'nde başarı ve kalıcılığa etkisi. Journal of Turkish Science Education, 6(2), 115-128.

Heath, M. (2005). Are you ready to go digital?: The pros and cons of electronic portfolio development. Library Media Connection, 23(7), 66.

Hewett, S. M. (2004). Electronic portfolios: Improving instructional practices. TechTrends, 48(5), 26-30. 
Jaekel, K. S. (2020). Benefits and challenges: Implementing e-portfolios in a graduate student affairs preparation program. College Student Affairs Journal, 38(2), 172-185.

Kabilan, M. K., \& Khan, M. A. (2012). Assessing pre-service English language teachers' learning using e-portfolios: Benefits, challenges and competencies gained. Computers \& Education, 58(4), 1007-1020.

Kan, A. (2019). Ölçmenin temel kavramları. H. Atılgan (Ed.), Eğitimde ölçme ve değerlendirme (s. 19-42) içinde. Ankara: Anı Yayıncılık.

Kan, A. (2007). Portfolyo değerlendirme. Hacettepe Üniversitesi Eğitim Fakültesi Dergisi, 32(32), 133-144.

Karakuş, M. (2010). Çağdaş denetim yaklaşımları. Fırat Üniversitesi Sosyal Bilimler Dergisi, 20(2), 181-200.

Kilmen, S. (2019). Ölçme ve değerlendirmede temel kavramlar. R. N. Çıkrıkçı (Ed.), Eğitimde ölçme ve değerlendirme (s. 1-24) içinde. Ankara: Anı Yayıncılık.

Korkmaz, H. ve Kaptan, F. (2002). Fen eğitiminde öğrencilerin gelişimini değerlendirmek için portfolyo kullanımı üzerine bir inceleme. Hacettepe Üniversitesi Eğitim Fakültesi Dergisi, 23(23), 167-176.

Korkmaz, H. ve Kaptan, F. (2005). Fen eğitiminde ögrencilerin gelişimini değerlendirmek için elektronik portfolyo kullanımı üzerine bir inceleme. TOJET: The Turkish Online Journal of Educational Technology, 4(1), 1303-6521.

Kutlu, Ö., Karakaya, İ. ve Doğan, D. (2017). Ölçme ve değerlendirme: Performansa ve portfolyoya dayalı durum belirleme. Ankara: Pegem Akademi.

Ledoux, M. W., \& McHenry, N. (2006). Electronic portfolio adoption for teacher education candidates. Early Childhood Education Journal, 34(2), 103-116.

Lin, Q. (2008). Preservice teachers' learning experiences of constructing e-portfolios online. The Internet and Higher Education, 11(3-4), 194-200.

Lorenzo, G., \& Ittelson, J. (2005). An overview of e-portfolios. Educause Learning Initiative, 1(1), 1-27.

Mason, R., Pegler, C., \& Weller, M. (2004). E-portfolios: An assessment tool for online courses. British Journal of Educational Technology, 35(6), 717-727.

Matthews, B., \& Ross, L. (2010). Research methods: A practical guide for the social sciences. Pearson.

Maxwell, J. A. (1992). Understanding and validity in qualitative research. Harvard Educational Review, 62(3), 279-300.

Merriam, S. B. (2013). Nitel araştırma: Desen ve uygulama için bir rehber. Ankara: Nobel.

Meyer, B., \& Latham, N. (2008). Implementing electronic portfolios: Benefits, challenges, and suggestions. Educause Quarterly, 31(1), 34.

Mihladız, G. (2007). Illköğretim fen bilgisi öğretiminde portfolyo uygulamasının öğrencilerin akademik başarılarına ve derse yönelik tutumlarına etkisi. (Yayınlanmamış Yüksek Lisans Tezi). Muğla Üniversitesi Fen Bilimleri Enstitüsü. Muğla.

Miles, M. B., \& Huberman, A. M. (1994). An expanded sourcebook qualitative data analysis. United States of America: Sage Publications.

Milli Eğitim Bakanlığı. (2018). Sosyal Bilgiler dersi öğretim programı. Erişim adresi: https://mufredat.meb.gov.tr/Dosyalar/201812103847686SOSYAL\%20B\%C4\%B0LG\%C 4\%B0LER\%20\%C3\%96\%C4\%9ERET\%C4\%B0M\%20PROGRAMI\%20.pdf 
Mills, G. E. (2007). Action research: A guide for the teacher researcher (3th Edition). New Jersey: Pearson.

Milman, N., \& Kilbane, C. (2005). Digital teaching portfolios: Catalysts for fostering authentic professional development. Canadian Journal of Learning and Technology/La Revue Canadienne de L'apprentissage et de la Technologie, 31(3).

Ngui, W., Pang, V., \& Hiew, W. (2020). Designing and Developing an e-Portfolio for Second Language Learners in Higher Education. International Journal of Information and Education Technology, 10(5) 362-366.

Nicolaidou, I. (2013). E-portfolios supporting primary students' writing performance and peer feedback. Computers \& Education, 68, 404-415.

Özçelik, D. A. (2018). Ölçme ve değerlendirme. Ankara: Pegem Akademi.

Özgür, H. (2016). Facebook sosyal ağına entegre e-portfolyo yazılımının akademik başarı ve öğretim sürecinde kullanımına yönelik tutuma etkisi. Sakarya University Journal of Education, 6(1), 38-56.

Özyenginer, E. (2006). Bilgisayar dersinde elektronik portfolyo yöntemi kullanımı üzerine bir çalışma. (Yayınlanmamış Doktora Tezi). Dokuz Eylül Üniversitesi Eğitim Bilimleri Enstitüsü. İzmir.

Parker, M., Ndoye, A., \& Ritzhaupt, A. D. (2012). Qualitative analysis of student perceptions of e-portfolios in a teacher education program. Journal of Digital Learning in Teacher Education, 28(3), 99-107.

Patton, M. Q. (2014). Qualitative research \& evaluation methods: Integrating theory and practice (4th Ed.). United States of America: Sage Publications, Inc.

Paulson, F. L., Paulson, P. R., \& Meyer, C. A. (1991). What makes a portfolio a portfolio. Educational Leadership, 48(5), 60-63.

Polat, M. ve Köse, Y. (2013). Okullarda bir performans değerlendirme araci olarak eportfolyo kullanimina yönelik ilköğretim öğretmenlerinin görüşleri. Bilgisayar ve Ĕgitim Araştırmaları Dergisi, 1(1), 57-82.

Poole, P., Brown, M., McNamara, G., O'Hara, J., O'Brien, S., \& Burns, D. (2018). Challenges and supports towards the integration of ePortfolios in education. Lessons to be learned from Ireland. Heliyon, 4(11), 2-23.

Sata, M., \& Karakaya, I. (2020). Investigation of the use of electronic portfolios in the determination of student achievement in higher education using the Many-Facet Rasch Measurement Model. Educational Policy Analysis and Strategic Research, 15(1), 7-21.

Semerci, Ç. (2015). Eğitimde ölçme ve değerlendirme. E. Karip (Ed.), Ölçme ve değerlendirme (s. 232-292) içinde. Ankara: Pegem Akademi.

Shriner, M., Clark, D. A., Nail, M., Schlee, B. M., \& Libler, R. (2010). Social studies instruction: Changing teacher confidence in classrooms enhanced by technology. The Social Studies, 101(2), 37-45.

Stake, R. E. (2010). Qualitative research: Studying how things work. Guilford Press.

Struyven, K., Blieck, Y., \& De Roeck, V. (2014). The electronic portfolio as a tool to develop and assess pre-service student teaching competences: Challenges for quality. Studies in Educational Evaluation, 43, 40-54.

Totter, A., \& Wyss, C. (2019). Opportunities and challenges of e-portfolios in teacher education. Lessons learnt. REM-Research on Education and Media, 11(1), 69-75. 
Turgut, M. F. ve Baykul, Y. (2019). Ĕgitimde ölçme ve değerlendirme. Ankara: Pegem Akademi.

Tüfekçi Aslim, S. (2014). Yapılandırmacı yaklaşım. S. Büyükalan Filiz (Ed.), Öğrenme öğretme kuram ve yaklaşımları (s.336-351) içinde. Ankara: Pegem Akademi.

Ülker, F. T., Ünlü, S. ve Usta, E. (2021). Fen Bilgisi öğretmen adaylarının e-portfolyo kullanımına yönelik görüşlerinin incelenmesi: Bir eylem araştırması. Turkish Journal of Primary Education, 6(1), 1-17.

Valencia, S. (1990). Assessment: A portfolio approach to classroom reading assessment: The whys, whats, and hows. The Reading Teacher, 43(4), 338-340.

Yeşilyaprak, B. ve Uçar, E. (2019). Öğrenmeden öğretime. B. Yeşilyaprak (Ed.), Eğitim psikolojisi gelişim-öğrenme-öğretim (s. 338-428) içinde. Ankara: Pegem Akademi.

Yin, R. K. (2018). Case study research and applications: Design and methods. Thousand Oaks, California: Sage.

Yusuf, B. (2017). Using an e-portfolio for teaching and teacher continuous learning: A process for professional development enhancement. In Amzat, I. H. \& Valdez, N. P. (Ed.), Teacher empowerment toward professional development and practices (pp. 295-307). Singapore: Springer.

Zeybek, G. (2019). Veritabanı organizasyonu dersinde elektronik portfolyo uygulamalarının akademik başarnya etkisi. Afyon Kocatepe Üniversitesi Sosyal Bilimler Dergisi, 21(4), 1045-1058.

\section{EXTENDED ABSTRACT}

\section{Introduction}

This study aims to examine the experiences of social studies teacher candidates regarding the electronic portfolio (e-portfolio) process.

Technology deepens its impact on our lives. In particular, educational processes are undergoing a serious transformation. The effect of the transformation from the teaching dimension to the measurement and evaluation processes can be seen. In terms of measurement and evaluation, it is seen that traditional portfolios have been replaced by electronic portfolios. An electronic portfolio, in its shortest definition, is defined as the transfer of a traditional portfolio to the digital environment. The e-portfolio includes all the advantages of the traditional portfolio, as well as many unique advantages. Thanks to the e-portfolio, students' digital skills can be strengthened, feedback can be carried out faster and more effectively, and 24/7 access to the developed products can be provided. On the contrary, some problems may be experienced in the e-portfolio process. These difficulties can be listed as the problem of accessing the internet, taking too much time, increasing the workload, and inexperienced students not getting used to the process.

\section{Methods}

This research was designed as a case study based on qualitative research. In the research, the focus was on social studies teacher candidates' use of e-portfolio in the evaluation processes in the "Material Development in Social Studies Teaching" course, which is an elective course in the third year of the Social Studies Education Department. The case was examined for 10 weeks. The study group of the research consists of 10 social studies teacher candidates. A purposive sampling method was used to determine the participants. The data collection tools of 
the research are focus group interview, researcher diary, and reflection papers. Qualitative content analysis was used in the analysis of the research data. In this process, first, the data was read several times, then the coding was carried out, and finally, the categories were revealed. In this process, related codes were brought together, and the categories of "Personal Effects", "Peer Interaction", "Student-Academician Interaction", "Digital Effects" and "Problems" were revealed.

\section{Results, Discussions, and Conclusion}

As a result of the research, it has been reached that the use of e-portfolio provides many personal benefits to social studies teacher candidates, makes peer interaction effective, deepens academician-student interaction, and provides digital benefits due to the use of online media. At the same time, there are some problems in the process. The use of an e-portfolio improves the academic self-regulation skills of social studies teacher candidates. There are many studies in the literature that support this result (Akgün \& Şahin Kölemen, 2020; Alexiou \& Paraskeva, 2010; Güven \&Aydoğdu, 2009; Erdoğan, 2006; Mihlâz, 2007). In the research, it was concluded that the use of e-portfolio contributed to the efficient use of time by the social studies teacher candidates. However, there are also studies showing that creating and archiving e-portfolios is time-consuming (Barış \& Tosun, 2013; Erten, 2015; Gök, Baş \& Ayaz, 2020). As a result of the research, it has been reached that the use of e-portfolio provides the participants with individual benefits for permanent learning, preventing test anxiety, and reducing workload. Similar studies are showing that the use of e-portfolios contributes to permanent learning (Corwin, 2003; Erten, 2015; Hewett, 2004; Milman \& Kilbane, 2005; Özgür, 2016). Barış and Tosun (2013) stated that students' passing through a measurement and evaluation process with low test anxiety enabled them to develop positive ideas about the use of e-portfolio.

In line with the findings, it was concluded that social studies teacher candidates made up for the deficiencies in their homework, reflected different perspectives on their homework, and deepened their academic knowledge, thanks to peer interaction in the e-portfolio process. Similarly, Gennip et al. (2009) also concluded that students who received qualified peer feedback gained more learning advantages than students who received less qualified peer feedback. Another conclusion is that the interaction between the student and the academician in the e-portfolio process is an effective tool in monitoring and shaping students academically. A study supporting this result was carried out by Birgin (2008). In the research, it was concluded that the e-portfolio strengthens the interaction between the teacher and the student and that the teachers get to know the student better and shape the teaching. In the study, it has been concluded that using an e-portfolio provides benefits in storing products, organizing, accessing products, and reducing costs. There are many studies supporting these results (Aktay and Gültekin, 2014; Driessen et al., 2007; Kim, 2001). Besides it was concluded that the social studies teacher candidates experienced individual and technology-related problems in the eportfolio process, but they did not experience any problems related to the essence of e-portfolio use. There are many studies supporting this result (Aktay \& Gültekin, 2014; Barış \& Tosun, 2014; Erten, 2015; Kabilan \& Khan, 2011; Totter \& Wyss, 2019). 